\title{
a2-Chimaerin, a Cdc42/Rac1 Regulator, Is Selectively Expressed in the Rat Embryonic Nervous System and Is Involved in Neuritogenesis in N1E-115 Neuroblastoma Cells
}

\author{
Christine Hall, ${ }^{1}$ Gregory J. Michael,, ${ }^{1,2}$ Nansi Cann, ${ }^{1,2}$ Giovanna Ferrari, ${ }^{1,2}$ Mabel Teo, ${ }^{1,2}$ Tom Jacobs, ${ }^{1}$ \\ Clinton Monfries, ${ }^{1,2}$ and Louis Lim ${ }^{1,2}$ \\ ${ }^{1}$ Department of Neurochemistry, Institute of Neurology, University College London, London WC1N 1PJ, United Kingdom, \\ and ${ }^{2}$ Glaxo/IMCB Group, Institute of Molecular and Cell Biology, National University of Singapore, Singapore 117609
}

Neuronal differentiation involves Rac and Cdc42 GTPases. $\alpha$-Chimaerin, a Rac/Cdc42 regulator, occurs as $\alpha 1$ - and alternatively spliced Src homology 2 (SH2) domain-containing $\alpha 2-$ isoforms. $\alpha 2$-chimaerin mRNA was highly expressed in the rat embryonic nervous system, especially in early postmitotic neurons. $\alpha 1$-chimaerin mRNA was undetectable before embryonic day 16.5. Adult $\alpha 2$-chimaerin mRNA was restricted to neurons within specific brain regions, with highest expression in the entorhinal cortex. $\alpha 2$-chimaerin protein localized to neuronal perikarya, dendrites, and axons. The overall pattern of $\alpha 2-$ chimaerin mRNA expression resembles that of cyclindependent kinase regulator p35 (CDK5/p35) which participates in neuronal differentiation and with which chimaerin interacts. To determine whether $\alpha 2$-chimaerin may have a role in neuronal differentiation and the relevance of the $\mathrm{SH} 2$ domain, the morphological effects of both chimaerin isoforms were investigated in N1E-115 neuroblastoma cells. When plated on poly-lysine, transient $\alpha 2$-chimaerin but not $\alpha 1$-chimaerin transfectants formed neurites. Permanent $\alpha 2$-chimaerin transfectants gener- ated neurites whether or not they were stimulated by serum starvation, and many cells were enlarged. Permanent $\alpha 1-$ chimaerin transfectants displayed numerous microspikes and contained F-actin clusters, a Cdc42-phenotype, but generated few neurites. In neuroblastoma cells, $\alpha 2$-chimaerin was predominantly soluble with some being membrane-associated, whereas $\alpha 1$-chimaerin was absent from the cytosol, being membrane- and cytoskeleton-associated, paralleling their subcellular distribution in brain. Transient transfection with $\alpha 2-$ chimaerin mutated in the $\mathrm{SH} 2$ domain $(\mathrm{N} 94 \mathrm{H})$ generated an $\alpha 1$-chimaerin-like phenotype, protein partitioned in the particulate fraction, and in NGF-stimulated pheochromocytoma cell line 12 (PC12) cells, neurite formation was inhibited. These results indicate a role for $\alpha 2$-chimaerin in morphological differentiation for which its $\mathrm{SH} 2$ domain is vital.

Key words: $\alpha 2$-chimaerin; Rac; Cdc42; GTPase; GAP; SH2; neurite outgrowth; embryonic brain; N1E-115 neuroblastoma; PC12; cdk5/p35; Crmp
Neuronal differentiation involves Rho family GTPases that trigger the morphological changes underlying altered cell adhesion, neurite outgrowth, and migration. In N1E-115 neuroblastoma cells, activation of Cdc42 and Rac1 generates filopodia and lamellipodia, respectively, required for the formation of neuritic projections, acting antagonistically with Rho (Kozma et al., 1997; van Leeuwen et al., 1997; Sarner et al., 2000). In primary neurons, inhibition of Rho signaling promotes neurite outgrowth (Bito et al., 2000), and Rho family GTPases are involved in specification of axonal and dendritic morphologies (Luo et al., 1996; Threadgill et al., 1997; Lee et al., 2000). Axonal outgrowth is modulated by guidance cues, including Sema3A, which causes neuronal growth cone collapse in an Rac1-dependent manner (Jin and Strittmatter, 1997; Vastrik et al., 1999). The developmental expression patterns of the Rac exchange factor Tiam-1 (Ehler et al., 1997) and Rac-regulated Cdk5/p35 kinase (Tsai et al., 1993; Nikolic et al., 1998; Zheng et al., 1998) are supportive of roles for

Received Sept. 5, 2000; revised April 30, 2001; accepted May 3, 2001.

This research was supported in part by the Glaxo/Singapore Research Fund. We thank P. R. Kolatkar, IMCB (Singapore) for assistance in structural analysis.

Correspondence should be addressed to Dr. Christine Hall, Institute of Neurology, University College London, 1 Wakefield Street, London WC1N 1PJ, UK. E-mail:C.Hall@ion.ucl.ac.uk.

G. J. Michael's present address: Neuroscience Section, Division of Biomedical Sciences, Queen Mary and Westfield College, Mile End Road, London E1 4NS, UK. Copyright (C) 2001 Society for Neuroscience 0270-6474/01/215191-12\$15.00/0
Rac1 in neural differentiation and cell migration. Both Tiam-1 and Cdk5 kinase promote neurite outgrowth in vitro (Nikolic et al., 1996; van Leeuwen et al., 1997), and p35- and Cdk5-knockout mice have defects in cortical lamination (Ohshima et al., 1996; Chae et al., 1997; Kwon et al., 1998).

In N1E-115 neuroblastoma cells, microinjected $\alpha 1$-chimaerin promotes the formation of filopodia and lamellipodia in neuritic growth cones; this requires $\mathrm{Cdc} 42$ and $\mathrm{Rac} 1$ participation and implicates $\alpha 1$-chimaerin as a putative effector for these GTPases (Kozma et al., 1996). $\alpha 2$-chimaerin is an alternatively spliced isoform, whose N-terminal of 185 amino acid residues encompassing an Src homology 2 (SH2) domain replaces the N-terminal 58 amino acid sequence of $\alpha 1$-chimaerin (Hall et al., 1993). A cysteine-rich domain and a GAP domain that acts in vitro on Rac1 (Diekmann et al., 1991; Manser et al., 1992) are common to both isoforms and conserved in $\beta$-chimaerin. The $\mathrm{N}$-terminals ( $\mathrm{SH} 2-$ containing) of $\alpha 2$ - and $\beta 2$-chimaerin have $72 \%$ similarity with precise conservation of the sequence divergence point in $\alpha 1-/ \alpha 2-$ and $\beta 1-/ \beta 2$-chimaerins (Hall et al., 1993; Leung et al., 1993, 1994). $\beta 2$-chimaerin is developmentally expressed in cerebellar granule cells, whereas $\alpha 1$-chimaerin occurs in Purkinje cells (Lim et al., 1992; Leung et al., 1994). $\beta 1$-chimaerin is testis-specific.

Here we describe the expression pattern of $\alpha 2$-chimaerin in the rat embryonic nervous system. Its selective expression in postmitotic neurons suggests a role in neuronal differentiation. To in- 
vestigate the effects of chimaerin on neuronal morphology, $\alpha 2$ chimaerin and $\alpha 1$-chimaerin were expressed in N1E-115 neuroblastoma and pheochromocytoma cell line 12 (PC12) cells. $\alpha 2$-chimaerin promotes neuritogenesis in permanent N1E-115 neuroblastoma cell lines, being substantially more effective than $\alpha 1$-chimaerin. Cells transiently transfected with $\alpha 2$-chimaerin, but not $\alpha 1$-chimaerin, formed neurites. As in the brain, $\alpha 2$ - and $\alpha 1$-chimaerin are respectively enriched in soluble and particulate fractions of transfected cells. An amino acid substitution (N94H) of the $\mathrm{SH} 2$ domain (which abolishes interaction of $\alpha 2$-chimaerin with putative targets in vitro) altered its distribution, morphological effects, and inhibited neurite formation, implicating the $\mathrm{SH} 2$ domain in the distinct regulation of $\alpha 2$-chimaerin and its effects on neuronal morphology.

\section{MATERIALS AND METHODS}

Tissue preparation. For in situ hybridization, embryos and brains of Sprague Dawley rats were frozen in isopentane at $-40^{\circ} \mathrm{C}$. Sections $(12$ $\mu \mathrm{m})$ were cut on a cryostat and thaw-mounted onto acid-cleaned slides coated with $2 \%$ 3-aminopropyltriethoxysilane (Sigma, Poole, UK) and stored at $-70^{\circ} \mathrm{C}$. For immunohistochemistry, rat brains were perfused with saline under terminal anesthesia, followed by $4 \%$ paraformaldehyde in PBS, $\mathrm{pH} \mathrm{7.4,} \mathrm{and} \mathrm{post-fixed} \mathrm{overnight} \mathrm{in} \mathrm{the} \mathrm{same} \mathrm{fixative.} \mathrm{Free-}$ floating sections $(40 \mu \mathrm{m})$ were rinsed extensively with PBS before staining.

In situ hybridization. Oligonucleotide probes used for in situ hybridization were: sequences complementary to $\alpha 2$-chimaerin-specific $5^{\prime}$ coding sequence nt 141-184 or nt 330-373, a sequence overlapping the splice junction (nt 537-580) between $\alpha 2$-chimaerin-specific and common $\alpha$-chimaerin exons (Hall et al., 1993), and an $\alpha 1$-chimaerin $5^{\prime}$ untranslated region oligonucleotide (nt 304-348) (Lim et al., 1992). Sense oligonucleotides of the $\alpha 2$-chimaerin sequences were used as controls, and competition of specific labeling was achieved by adding a 20 -fold excess of the unlabeled oligonucleotide. Oligonucleotide probes were $3^{\prime}$ end-labeled with $\left(\gamma^{33} \mathrm{P}\right) \mathrm{dATP}$ and terminal transferase (NEN, Hounslow, UK). Pretreatment of sections was performed according to Brandt et al. (1987). Frozen sections were fixed $5 \mathrm{~min}$ in $4 \%$ paraformaldehyde, rinsed with PBS, and incubated for $10 \mathrm{~min}$ in $0.25 \%$ acetic anhydride in $0.1 \mathrm{~m}$ triethanolamine, $\mathrm{pH}$ 8.0. Sections were dehydrated and finally delipidated for $5 \mathrm{~min}$ in chloroform. Hybridization was performed overnight at $37^{\circ} \mathrm{C}$ in $2 \times \mathrm{SSC}, 50 \%$ formamide, $5 \times$ Denhardt's solution, $10 \%$ dextran sulfate, $0.2 \%$ SDS, $20 \mu \mathrm{g} / \mathrm{ml}$ yeast tRNA, $100 \mu \mathrm{g} / \mathrm{ml}$ sheared salmon sperm DNA, $10 \mu \mathrm{g} / \mathrm{ml}$ poly(A), and oligonucleotide probe diluted to $2 \times 10^{7} \mathrm{cpm} / \mathrm{ml}$. Glass coverslips were removed in $2 \times \mathrm{SSC}$ at room temperature (RT). Washes, $(15 \mathrm{~min})$ at $\mathrm{RT}$ in $2 \times \mathrm{SSC}$ and twice at $50^{\circ} \mathrm{C}$ in $1 \times \mathrm{SSC}$ followed by a high-stringency wash at $50-55^{\circ} \mathrm{C}$ in $0.2 \times$ SSC for $\alpha 2$-chimaerin probes or $0.1 \times$ SSC for the $\alpha 1$-chimaerin probe. Sections were washed a further $2 \mathrm{hr}$ at RT in $1 \times \mathrm{SSC}$ and dehydrated before exposure to $\beta$-max Hyperfilm (Amersham Pharmacia Biotech, Little Chalfont, UK) or dipping in Hypercoat LM-1 nuclear emulsion (Amersham Pharmacia Biotech). Exposure times were 2 and 4-6 weeks, respectively. Emulsion-dipped sections were counterstained with methyl green-pyronine stain (Sigma).

Immunocytochemistry. Sections were blocked for $30 \mathrm{~min}$ in $2 \%$ normal goat serum and $1 \%$ bovine serum albumin in PBS at RT and incubated with primary antiserum (1:5000-1:10,000 in blocking solution) for $48 \mathrm{hr}$ at $4^{\circ} \mathrm{C}$. Sections were incubated with biotinylated goat anti-rabbit IgG (Vector Laboratories, Peterborough, UK) (1:250), followed by Vectastain Elite avidin-biotin immunoperoxidase reagent (Vector Laboratories), and the peroxidase reaction was developed with $0.5 \mathrm{mg} / \mathrm{ml}$ 3,3'-diaminobenzidine and $0.02 \%$ hydrogen peroxide. Preabsorption of diluted antiserum with recombinant $\alpha 2$-chimaerin $(5 \mu \mathrm{M})$ was incubated overnight at $4^{\circ} \mathrm{C}$.

Preparation of antibodies. $\alpha 2$-chimaerin cleaved from GST $/ \alpha 2$ chimaerin with thrombin and purified as previously described (Hall et al., 1993) was used to raise antibodies in rabbits. For some experiments $\alpha 2$-chimaerin antibody was purified by affinity chromatography on glutathione-agarose and recombinant $\alpha 1$-chimaerin agarose columns to remove GST and $\alpha 1$-chimaerin reactivity.

Subcellular fractionation and Western blotting. Subcellular fractions were prepared from adult rat brain homogenate in isotonic sucrose (Whittaker and Barker, 1972). After centrifugation at $1000 \times g$, the supernatant was spun at $12,000 \times g$ to obtain the P2 pellet fraction containing mitochondria, myelin, and synaptosomes, from which synaptic plasma membranes were further purified by sucrose gradient centrifugation. The $12,000 \times g$ supernatant fraction was centrifuged at $100,000 \times$ $\mathrm{g}$ to obtain microsomal and cytosol fractions. Pellet fractions were washed with isotonic solution before solubilization in SDS electrophoresis buffer, and soluble fractions were concentrated using Centriprep concentrators (Amicon, Beverly, MA). SDS gel electrophoresis, Western immunoblotting with primary antibody, and secondary horseradish peroxidase-conjugated goat anti-rabbit IgG (Dako, Cambridge, UK), detected by ECL reagent (Amersham Pharmacia Biotech) was as described (Obermeier et al., 1998). GAP overlay assay to detect RacGAP activity was as described by Manser et al. (1992).

Site-directed mutagenesis of the $\alpha 2$-chimaerin SH2 domain, GAP domain, and cloning of chimaerin sequences. Point mutations in the $\mathrm{SH} 2$ domain were introduced in the full-length $\alpha 2$-chimaerin sequence in BSKII + 921.2 (Hall et al., 1993) at positions equivalent to those important for Src SH2-phosphopeptide interaction (Bibbins et al., 1993). Mutations were made using the Transformer Site-Directed Mutagenesis Kit (Clontech, Basingstoke, UK) and a selection oligonucleotide mutating BSK II+SacI site to an AatII site. Mutated sequences were identified by appropriate restriction enzyme digest, confirmed by sequence analysis, and subsequently cloned in pGEX-2TK and eukaryotic vectors.

The $\alpha 2$-chimaerin SH2 domain-containing N-terminal fragments (1160) encoded in an EcoRI/NdeI fragment (or the full-length coding sequence in an EcoRI/DraI fragment) excised from BSKII ${ }^{+} 921.2$ (Hall et al., 1993) were cloned into the SmaI site of pGEX-2TK. GST fusion proteins were purified by established methods (Manser et al., 1992).

$\alpha 1$ - and $\alpha 2$-chimaerin and mutated $\alpha 2$-chimaerin sequences were cloned into mammalian expression vectors pXJ40-HA, pXJ40-GFP, or pXJ41-HA (Xiao et al., 1991; Manser et al., 1997). pXJ40HA encodes a 10 amino acid hemagglutinin (HA) tag recognized by monoclonal antibody (Roche Diagnostics, Lewes, UK). pXJ40-GFP encodes green fluorescent protein in a sequence inserted between the EcoRI and BamHI sites. pXJ41-HA contains the neomycin resistance gene enabling G418 selection for permanent expression. Inserts of $\alpha 1$-chimaerin cDNA coding sequence in a FokI/BalI fragment (417-1534) from pBS-rlam631 (Lim et al., 1992), $\alpha 2$-chimaerin pBSK +921.2 EcoRI/XhoI fragment, and $\mathrm{SH} 2$ domain mutated sequences were cloned into the Klenow blunted BamHI site of pXJ40-HA, pXJ40-GFP, and pXJ41-HA. Chimaerin GAP domain mutations were made in pXJ40-GFP-chimaerin constructs by substitution of $\mathrm{nt} 920 \mathrm{C}$ for $\mathrm{G}$ (amino acid residue R304G) or by deletion of nine nucleotides encoding amino acid residues 303-305 YRV (303-305) and corresponding sequence in $\alpha 1$-chimaerin using the Quick Change site-directed mutagenesis kit (Stratagene, La Jolla, CA). These mutations involving a catalytically important conserved RhoGAP arginine residue eliminate or greatly reduce GAP activity (Ahmed et al., 1994; Barrett et al., 1997; Leonard et al., 1998; Taylor et al., 1999).

Transient and permanent transfection of N1E-115, COS-7, and PC12 cells and immunostaining. N1E-115 neuroblastoma cells or COS-7 cells were grown in DMEM with $10 \%$ fetal calf serum (FCS) and $1 \%$ antibiotic-antimycotic (Life Technologies, Paisley, UK) at $37^{\circ} \mathrm{C}$ with $5 \%$ $\mathrm{CO}_{2}$. Cells were transfected after $1 \mathrm{hr}$ of serum starvation using lipofectamine (Life Technologies) in DMEM (Sarner et al., 2000), and FCS $(5 \%)$ was replaced after $5 \mathrm{hr}$. PC12 cells plated on collagen and grown as previously described (Obermeier et al., 1998) were transfected in serumfree DMEM containing $1 \mu \mathrm{M}$ insulin using lipofectamine 2000 (Life Technologies). Serum-containing media was replaced after $16 \mathrm{hr}$, and NGF (100 ng/ml human recombinant; Sigma) was added. Transiently transfected cells were stained with anti-chimaerin, $\mathrm{p35}$, or neurofilament antibody and/or rhodamine-conjugated phalloidin (Sigma) as described (Kozma et al., 1996) and analyzed by confocal microscopy (Zeiss LSM410; Zeiss, Welwyn Garden City, UK). Cells transfected with pXJ41HA DNA constructs were grown in complete media containing $800 \mu \mathrm{g} / \mathrm{ml} \mathrm{G} 418$ (Life Technologies) for 2-3 weeks for selection and isolation of cell clones stably expressing chimaerin isoforms. Established chimaerin-expressing cell lines were subsequently used for transient transfection experiments with pXJ40-GFP or pXJ40-HA cDNA constructs encoding dominant negative Rac1 N17, Cdc42 N17 or chimaerin N94H.

Protein analysis. After $24 \mathrm{hr}$, transfected COS-7 or N1E-115 cells were lysed in $25 \mathrm{~mm}$ HEPES, pH 7.3, $20 \mathrm{~mm} \beta$-glycerophosphate, $0.3 \mathrm{M} \mathrm{NaCl}$, $1.5 \mathrm{mM} \mathrm{MgCl}_{2}, 0.2 \mathrm{~mm}$ EDTA, pH 8.0, $5 \%(\mathrm{w} / \mathrm{v})$ glycerol, $0.5 \%(\mathrm{w} / \mathrm{v})$ Triton X-100, $1 \mathrm{~mm}$ PMSF, $1 \mathrm{~mm}$ Na vanadate, $0.5 \mathrm{~mm}$ DTT, $5 \mu \mathrm{g} / \mathrm{ml}$ pepstatin, and $5 \mu \mathrm{g} / \mathrm{ml}$ aprotinin and centrifuged at $20,000 \times g$, for 10 
min at $4^{\circ} \mathrm{C}$. Pellet fractions were solubilized in SDS sample buffer. Alternatively, cells were sonicated in hypotonic buffer $(20 \mathrm{~mm}$ Tris-HCl, $\mathrm{pH} 7.0,10 \mathrm{~mm} \mathrm{KCl}$, and $2 \mathrm{~mm}$ PMSF), centrifuged at $100,000 \times \mathrm{g}$ for 1 $\mathrm{hr}$ at $4^{\circ} \mathrm{C}$, and the pellet fractions were extracted in $1 \%$ Triton $\mathrm{X}-100,140$ $\mathrm{mm} \mathrm{NaCl}, 10 \mathrm{~mm}$ Tris- $\mathrm{HCl}, \mathrm{pH} 7.5,2 \mathrm{~mm}$ PMSF, and centrifuged at $15,000 \times g$ for $10 \mathrm{~min}$ at $4^{\circ} \mathrm{C}$ to pellet the cytoskeletal fraction. Proteins were analyzed by SDS gel electrophoresis and Western blotting with anti-HA or anti- $\alpha 2$-chimaerin antibody.

Analysis of phosphotyrosine binding of chimaerin SH2 domain. Equal portions of Escherichia coli cell lysates $(10 \mathrm{ml})$ containing GST/ $\alpha 2$ chimaerin $\mathrm{SH} 2$ domain or mutated $\mathrm{SH} 2$ domains were incubated with either glutathione-agarose or phosphotyrosine-agarose (Sigma) in PBS and $1 \%$ Triton $\mathrm{X}-100$ for $1 \mathrm{hr}$ at $4^{\circ} \mathrm{C}$. After washing with PBS and $1 \%$ Triton X-100, bound proteins eluted in SDS sample buffer were analyzed by SDS gel electrophoresis and Coomassie blue staining or Western immunoblotting with anti- $\alpha 2$-chimaerin antibody.

\section{RESULTS}

\section{$\alpha 1-$ and $\alpha 2$-chimaerin mRNA expression are different in adult rat brain}

Using appropriate oligonucleotide probes (see Materials and Methods), we found $\alpha 1$ - and $\alpha 2$-chimaerin mRNA expression to differ substantially with the former being much higher in adult rat brain (Fig. $1 A_{A, C}$ ). Identical patterns of $\alpha 2$-chimaerin mRNA expression were obtained using two different probes (Fig. $1 A_{A, B}$ ), one from the unique $\alpha 2$-chimaerin $5^{\prime}$ sequence, and one spanning the junction between the unique $\alpha 2$ - and common chimaerin sequence. Neither half of the junctional probe detected any signal at the same hybridization stringency. Specificity of hybridization was also demonstrated by the absence of signal with sense strand oligonucleotide (Fig. $1 A_{D}$ ), by its being effectively competed by a 20-fold excess of nonradioactive oligonucleotide (Fig. 1B, control) and by the distinct pattern of hybridization obtained with $\alpha 2$ - and $\alpha 1$-chimaerin $5^{\prime}$-specific probes.

\section{$\alpha 2$-chimaerin mRNA is expressed in the embryonic nervous system in postmitotic neurons}

$\alpha 2$-chimaerin mRNA expression was highest in the PNS and CNS from E12.5 until birth (Fig. 1B). Neural crest derivatives including cranial and spinal sensory ganglia and autonomic ganglia, expressed high amounts, as did the adrenal gland, containing neural crest-derived chromaffin cells, by E20.5. This widespread early embryonic expression of $\alpha 2$-chimaerin mRNA contrasts with $\alpha 1$-chimaerin mRNA expression, which was virtually undetectable before E16.5. Embryonic expression of $\alpha 2$-chimaerin mRNA paralleled the caudal to rostral gradient of CNS maturation (Fig. 1B). At E12.5, the cephalic flexure region exhibited high expression, and more rostral regions exhibited lower expression (except for a few early differentiating structures). At E14.5, expression was high in more rostral areas, in the diencephalon and basal telencephalon. By E16.5 there was increased expression in the cortical plate to which postmitotic neurons have migrated.

Significantly, $\alpha 2$-chimaerin mRNA expression was transiently increased as neurons became postmitotic and migrated away from the neuroepithelium. Thus, whereas in the adult spinal cord expression was low, at E12.5 expression was high in the differentiating mantle layer motor neurons of the cord ventral horn, in contrast to neuroepithelium of the ventricular zone (Fig. $1 C_{C}$ ). Similarly at E16.5 in the cortex, the cortical plate consisting of postmitotic neurons showed increased expression relative to the underlying neuroepithelium (Fig. $1 C_{A}$ ), and in the cerebellum expression in differentiating cells was much higher than the adjacent neuroepithelium. Expression was also high in the developing olfactory epithelium (undetectable in neighboring respiratory epithelium) and retina (Fig. $1 B, C_{E}$ ). There was no expression in the choroid plexus (Fig. $1 C_{B}$ ).

\section{Changes in $\alpha 2$-chimaerin mRNA expression in postnatal brain development}

Until postnatal day 7, $\alpha 2$-chimaerin mRNA was evenly expressed in the isocortex (Fig. 2A). Between days 7 and 12, the expression pattern changed with two bands exhibiting much higher expression. The outer band corresponding to layers II-IV showed moderate expression, mRNA was barely detectable in layer V cells, but layer VIa displayed higher levels, and this further increased by day 17 . Over the same period, expression increased in cells in the rhomboid thalamic nucleus and its lateral wings (Fig. $2 A, B_{c}$ ).

\section{$\alpha 2-c h i m a e r i n$ mRNA expression in adult rat brain}

In the adult rat brain, $\alpha 2$-chimaerin mRNA expression was especially localized to specific structures (Fig. 2B, Table 1). In particular, structures of the telencephalon involved in the processing of olfactory information showed high to moderate expression. The anterior olfactory nucleus exhibited one of the highest levels of expression in the brain (Fig. $2 B_{a}$ ). Cells of the piriform cortex and the nucleus of the lateral olfactory tract also had moderate to high expression levels. Expression occurred throughout all areas of the cerebral cortex (Fig. $2 B_{a-e}$ ). In the neocortex, the pattern established after postnatal day 7 with the very high expression in layer VIa was maintained in the adult. Cells in layer V had the lowest expression in the neocortex. The highest expression was found in layers II and III of the entorhinal cortex. The lamina dissecans of the entorhinal cortex and the parasubiculum also showed relatively high expression (Fig. $2 B_{e, f}$ ). In the hippocampus, expression in the pyramidal cell layers CA1-4 was high and slightly lower in the granule cells of the dentate gyrus (Fig. $2 B_{c, d}$ ). In the basal ganglia, the striatum showed moderate expression (Fig. $2 B_{c}$ ). On emulsion-dipped sections, label was observed over cells with the appearance and distribution of medium-sized projection neurons.

Expression was moderate in most of the hypothalamic nuclei (Fig. $2 B_{c}$ ). The thalamus showed a restricted pattern of expression, with moderate levels in intralaminar and midline nuclei (Fig. $2 B_{c}$ ). Expression was also moderate in the brainstem with higher levels in some specific nuclei including the dorsal raphe nucleus, locus coeruleus, dorsal motor nucleus of the vagus nerve, and inferior olivary nucleus (Fig. $2 B_{e-h}$ ). Throughout the brain, $\alpha 2-$ and $\alpha 1$-chimaerin mRNAs had distinct but overlapping patterns of expression (Table 1).

\section{$\alpha 1-$ and $\alpha 2$-chimaerin protein distribution in adult rat brain cells}

We next investigated $\alpha 1$ - and $\alpha 2$-chimaerin protein expression, using polyclonal antisera raised against recombinant chimaerin C-terminal (Kozma et al., 1996) and full-length $\alpha 2$-chimaerin. The $\alpha 2$-chimaerin antibody reacted strongly with full-length protein and an N-terminal construct containing the first 49 amino acids and $\mathrm{SH} 2$ domain, but weakly with the isolated $\mathrm{SH} 2$ domain and not with the GAP domain (Fig. $3 A$ ). The $45 \mathrm{kDa} \alpha 2-$ chimaerin protein was present in brain cytosolic fractions and in both plasma membranes and microsomal fractions (Fig. 3B). Antibodies raised against the $\mathrm{C}$-terminal GAP domain detected $45 \mathrm{kDa}(\alpha 2$-chimaerin) and $38 \mathrm{kDa}(\alpha 1$-chimaerin) proteins, both of which displayed Rac GAP activity (Fig. 3B). $\alpha 1$-chimaerin immunoreactivity and corresponding RacGAP activity was predominantly found in microsomal fractions with small amounts in 


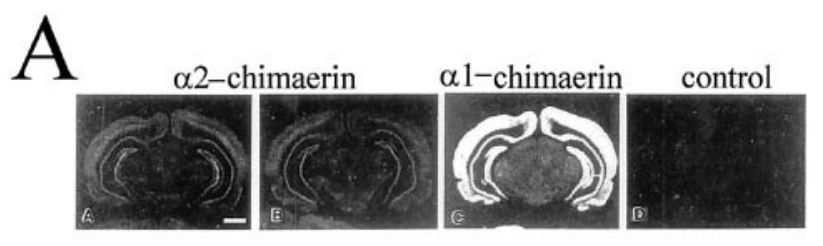

\section{$\mathrm{B}_{\alpha 2 \text {-chimaerin }}$}
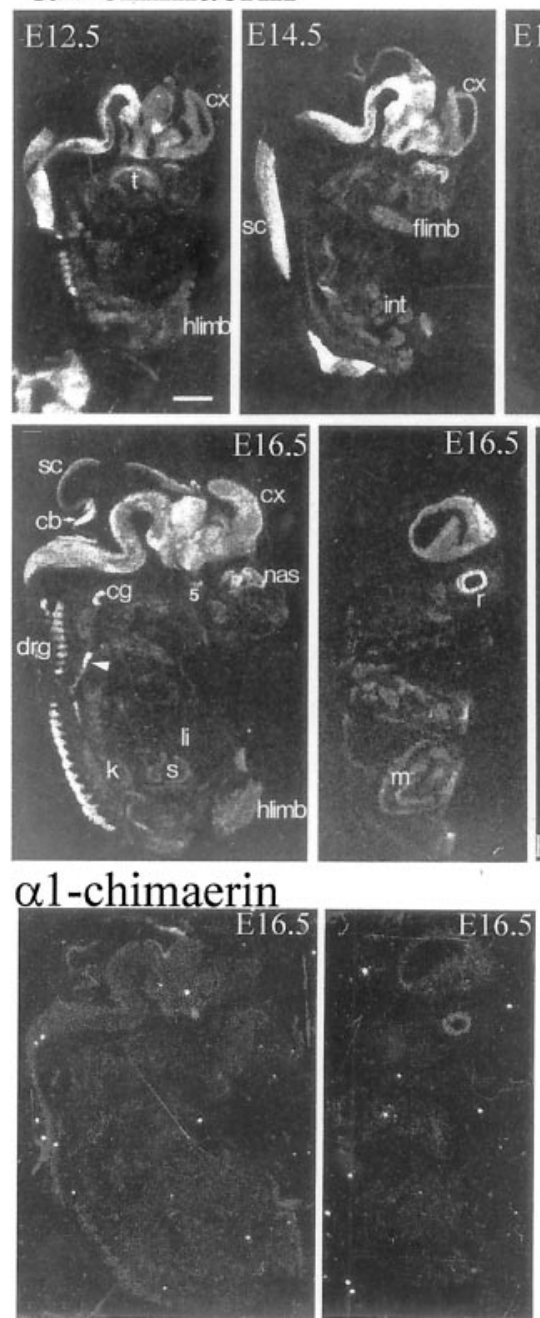
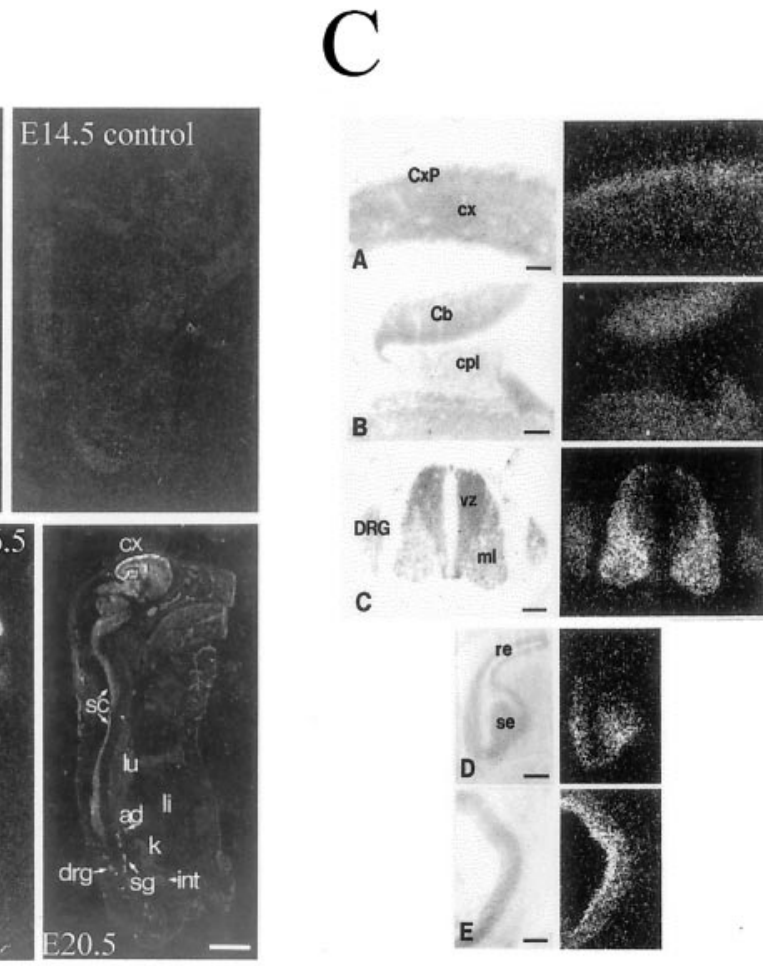

Figure 1. $\alpha 2$-chimaerin mRNA, but not $\alpha 1$-chimaerin mRNA, is highly expressed in embryonic nervous system. $A$, Specificity of detection of $\alpha 2$ - and $\alpha 1$-chimaerin mRNA was determined by in situ hybridization of coronal sections of adult rat brain with oligonucleotide probes complementary to $\alpha 2$-chimaerin N-terminal coding sequence $\left(A_{A}\right)$, an $\alpha 2$-chimaerin oligonucleotide spanning the point of sequence divergence from $\alpha 1$-chimaerin $\left(A_{B}\right)$, $\alpha 1$-chimaerin 5 'sequence, showing the higher level of expression of $\alpha 1$-chimaerin in adult brain $\left(A_{C}\right)$, and an $\alpha 2$-chimaerin sense strand control oligonucleotide $\left(A_{D}\right)$. Scale bar, $2 \mathrm{~mm}$. B, a2-chimaerin mRNA expression during embryonic development. At embryonic day 12.5 (E12.5), high levels of specific labeling were detected in central and peripheral nervous system with most intense signal in caudal structures. E14.5 and E16.5 embryos show progressively more rostral hybridization; the signal could be competed by a 20 -fold excess concentration of unlabeled oligonucleotide (E14.5 control); E16.5 embryos show strong hybridization to cerebral cortex and in a more lateral E16.5 section hybridization to the retina $(r)$. Although the nervous system clearly exhibits the highest levels of hybridization throughout embryonic development, various other structures including limb buds, smooth and striated muscle, and developing organs such as the kidney and lung are also slightly labeled at longer exposures. At $20 \mathrm{~d}$ (E20.5) moderate levels of hybridization are detected in most neural tissues with higher levels in sympathetic ganglia and in a band outlining the cerebral cortex. $a d$, Adrenal gland; $c b$, cerebellum; $c g$, cervical ganglion; col, colliculus; $c x$, cortex; $d r g$, dorsal root ganglion; int, intestine; flimb, forelimb; hlimb, hindlimb; $k$, kidney; li, liver; $l u$, lung; $m$, muscle; nas, nasal epithelium; $r$, retina; $s$, stomach; $s c$, spinal cord; sg, sympathetic ganglion; $t$, tongue; 5 , trigeminal ganglion. Hybridization to $\alpha 1$-chimaerin-specific oligonucleotide was detectable at E16.5. Central and lateral sections show very low levels of expression [compare with hybridization to $\alpha 2$-chimaerin specific oligonucleotide in corresponding (E16.5) sections above]. Scale bars: E12.5-E16.5, 1.5 mm; E20.5, 3.5 mm. $C$, $\alpha 2$-chimaerin mRNA expression in embryonic rat tissues at E12.5 and E16.5. Light-field photomicrographs of counterstained sections and corresponding dark-field in situ hybridization in emulsion-dipped slides: $\left(C_{A}\right)$ E16.5 cerebral cortex. Note the higher expression in the cortical plate $(C x P)$ relative to cortical neuroepithelium $(c x) . C_{B}$, E16.5; there is expression in the cerebellar anlage $(C b)$ but not in the adjacent choroid plexus $(c p l)$. $C_{C}$, E12.5; $\alpha 2$-chimaerin mRNA is present in dorsal root ganglion $(D R G)$ and at high levels in spinal cord mantle layer $(m l)$ but not in the ventricular zone $(v z)$. $C_{D}$, E16.5 olfactory sensory ( $\mathrm{se}$ ) but not respiratory epithelium (re) shows hybridization. $C_{E}$, E16.5; labeling of the retina is most intense over the inner band of cells. Scale bar, $150 \mu \mathrm{m}$. 

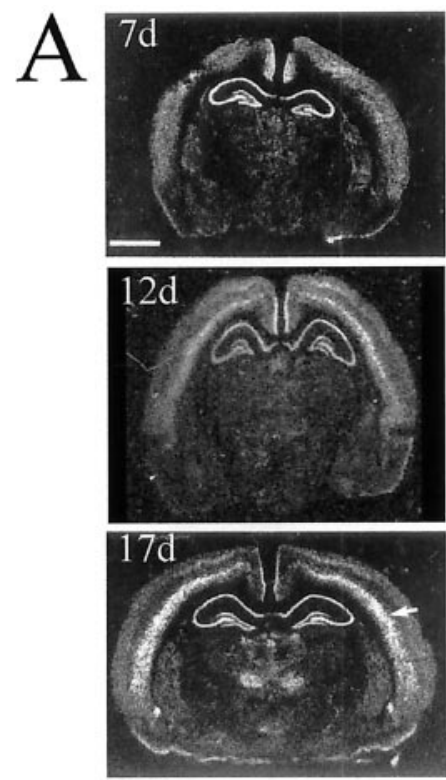
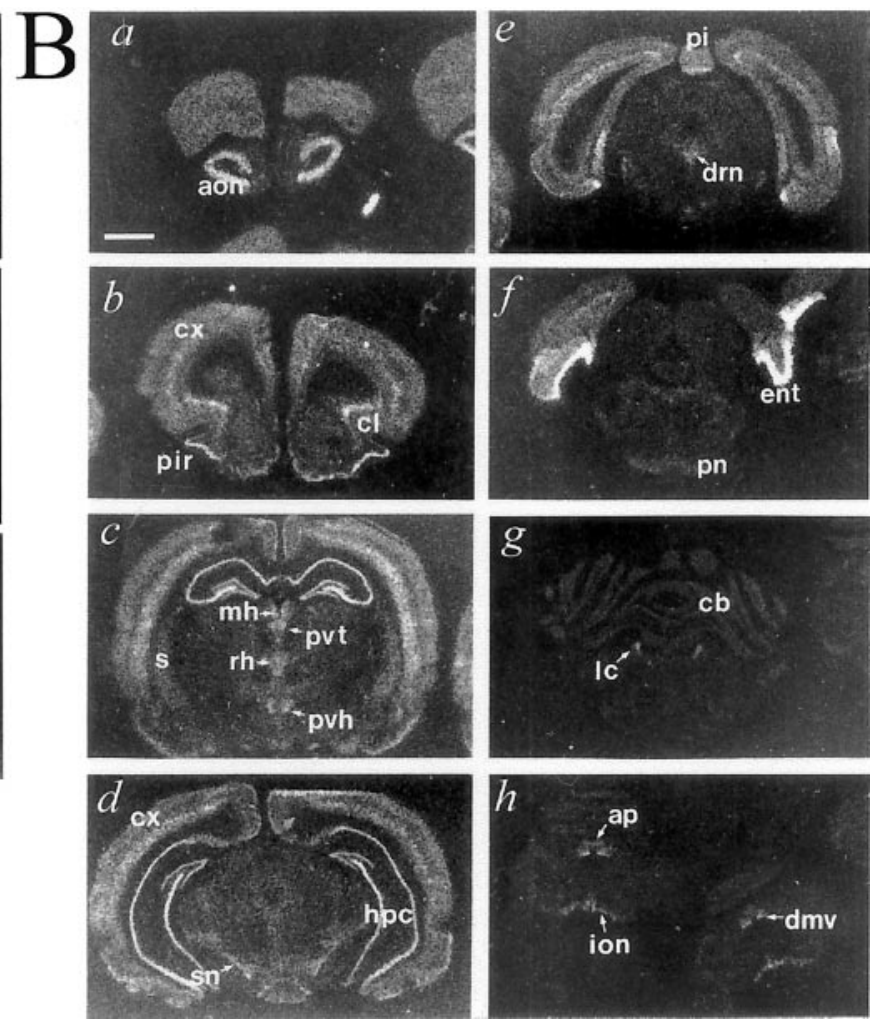

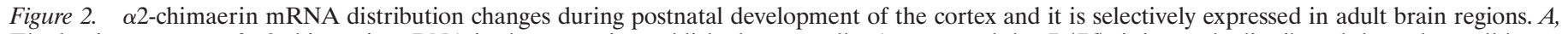

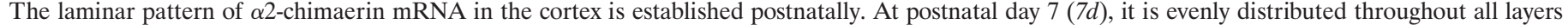

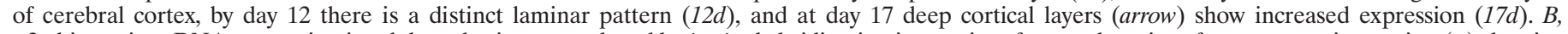

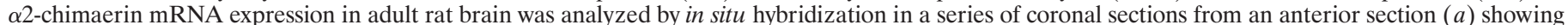

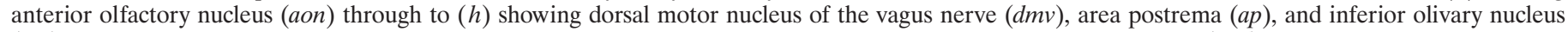

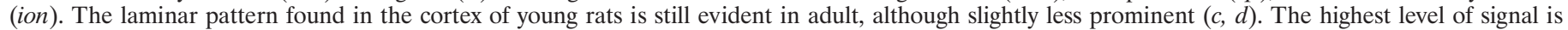

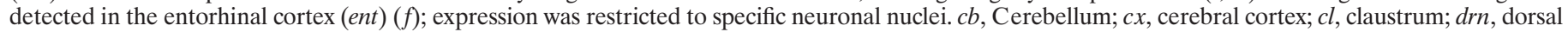

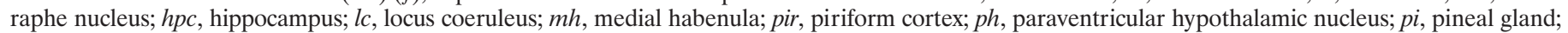
$p n$, pontine nucleus; $p t$, paraventricular thalamic nucleus; rh $\alpha$ rhomboid nucleus of the thalamus; $s$, striatum; sn, substantia nigra. Scale bar, 2 mm.

synaptic and plasma membrane fractions, but was absent from cytosol (Fig. 3B).

\section{Immunocytochemical localization of $\alpha 2$-chimaerin in brain}

The $\alpha 2$-chimaerin antiserum was used to analyze protein distribution in the adult rat brain (Figs. 3, 4). To verify the specificity of this antibody for $\alpha 2$-chimaerin, the pattern of immunoreactivity in cortex was compared with mRNA distribution shown by in situ hybridization (Fig. 3C). The pattern of cell bodies stained corresponded closely to the expression of $\alpha 2$ - but not of $\alpha 1$ chimaerin mRNA (Fig. $3 C$ ). Identical results were obtained using the polyclonal antiserum before or after its further purification to remove antibodies to GST and $\alpha 1$-chimaerin (data not shown). Control sections using antibody preabsorbed with $5 \mu \mathrm{M} \alpha 2$ chimaerin (or preimmune serum) were devoid of specific staining. The most dense immunohistochemical reaction was found in cells of the entorhinal cortex, claustrum, layer VIa of the neocortex, hippocampus, dorsal motor nucleus of the vagus, and inferior olivary nucleus (Fig. 4). The discrete localization of $\alpha 2$-chimaerin immunoreactivity in thalamic interlaminar and midline nuclei also paralleled distribution of $\alpha 2$-chimaerin mRNA (Fig. $4 A_{A}$ ). Neither astrocytes nor oligodendrocytes contained immunoreactivity.

Chimaerin immunoreactivity was found throughout the entire neuron, bar the nucleus. The cell staining often appeared punctate, except in intensely labeled cells where it was more homog- enous (Fig. $4 B_{A, D}$ ). Dendrites extending from the cell body had localized patchy staining (Fig. $4 B_{\mathrm{A}, \mathrm{D}}$ ). Axons were more homogenously stained and were visible in white matter tracts, including the alveus and internal capsule. Terminal fields of stained neurons also contained punctate labeling. In the hippocampal formation, terminations of the projections from the entorhinal cortex could be distinguished as bands of increased staining intensity in the neuropil of the outer two-thirds of the molecular layer of the dentate gyrus (Fig. $4 A_{D}$ ).

\section{Biochemical properties associated with the $\alpha 2$ - chimaerin $\mathrm{SH} 2$ domain}

To investigate the function of the $\alpha 2$-chimaerin $\mathrm{SH} 2$ domain, amino acid substitutions were made at positions predicted to be involved in phosphotyrosine or target peptide binding (Fig. 5A). The atypical N-terminal glutamic acid residue (E49) was mutated to the more usual tryptophan. Leucines were substituted for arginines R56 and R73, corresponding to the highly conserved $\alpha \mathrm{A} 2$ arginine and invariant $\beta \mathrm{B} 5$ arginine essential for phosphotyrosine binding (Waksman et al., 1992, 1993; Bibbins et al., 1993), and histidine was substituted for an atypical asparagine (N94H), which aligns with Src $\beta$ D4 (Src H201) (Fig. 5A). Residues in this $\beta \mathrm{D}$ region of $\mathrm{Src}$ are involved in target phosphopeptide selectivity (Songyang et al., 1995). Wild-type chimaerin SH2 domain bound phosphotyrosine-agarose, as did E49W and $\mathrm{N} 94 \mathrm{H}$ 


\begin{tabular}{|c|c|c|}
\hline & $\alpha 2$-chimaerin & $\alpha 1$-chimaerin \\
\hline Olfactory bulb, anterior nucleus & +++ & ++++ \\
\hline \multicolumn{3}{|l|}{ Cortex } \\
\hline Layers 2-4 & ++ & ++++ \\
\hline Layers 6 & +++ & ++++ \\
\hline Piriform & ++ & ++++ \\
\hline Cingulate & +++ & ++++ \\
\hline Entorhinal & ++++ & ++++ \\
\hline \multicolumn{3}{|l|}{ Lamina dissecans entorhinal cor- } \\
\hline tex & +++ & ++++ \\
\hline Hippocampus, dentate gyrus & +++ & ++++ \\
\hline \multicolumn{3}{|l|}{ Amygdala } \\
\hline Nucleus of olfactory tract & + & ++++ \\
\hline Basolateral nucleus & - & +++ \\
\hline \multicolumn{3}{|l|}{ Basal ganglia } \\
\hline Striatum & ++ & +++ \\
\hline Substantia nigra & ++ & + \\
\hline \multicolumn{3}{|l|}{ Epithalamus } \\
\hline Medial habenula & +++ & + \\
\hline Pineal gland & ++ & + \\
\hline \multicolumn{3}{|l|}{ Thalamus } \\
\hline Paraventricular nucleus & +++ & + \\
\hline Other nuclei & ++ & + \\
\hline \multicolumn{3}{|l|}{ Hypothalamus } \\
\hline Suprachiasmatic nucleus & + & + \\
\hline Supraoptic/paraventricular nucleus & ++ & + \\
\hline Dorsomedial nucleus & - & ++ \\
\hline Venromedial nucleus & - & ++ \\
\hline Arcuate nucleus & ++ & + \\
\hline Medial preoptic & + & + \\
\hline Median preoptic nucleus & ++ & + \\
\hline \multicolumn{3}{|l|}{ Brainstem } \\
\hline Sucommisural organ & ++ & + \\
\hline Parabigeminal nucleus & ++ & ++ \\
\hline Locus coeruleus & ++ & + \\
\hline Dorsal motor nucleus vagus & +++ & + \\
\hline \multicolumn{3}{|l|}{ Cerebellum } \\
\hline Purkinje cells & - & +++ \\
\hline Granule cells & - & - \\
\hline Red nucleus & - & + \\
\hline Inferior olivary nucleus & +++ & + \\
\hline
\end{tabular}

mutants (Fig. 5B). Mutation of arginines R73L and R56L abolished this phosphotyrosine interaction.

None of the SH2 domain mutations affected GAP activity of $\alpha 2$-chimaerin in vitro (data not shown). This activity is $\sim 10$-fold greater than that of $\alpha 1$-chimaerin in the absence of lipids and is comparable with that of GAP domain alone, suggesting a regulatory function for the N-terminal not reliant on the $\mathrm{SH} 2$ domain. $\alpha 1$ - and $\alpha 2$-chimaerin GAP activities were both increased by lipids.

\section{Subcellular distribution of $\alpha 2$-chimaerin is altered by an $\mathrm{SH} 2$ domain mutation}

$\alpha 1$ - and $\alpha 2$-chimaerin isoforms and the four $\alpha 2$-chimaerin $\mathrm{SH} 2$ domain mutants were expressed in COS-7 and N1E-115 neuroblastoma cells to investigate the effect of the alternately spliced $\mathrm{N}$-terminal SH2-containing sequence. Proteins of the expected

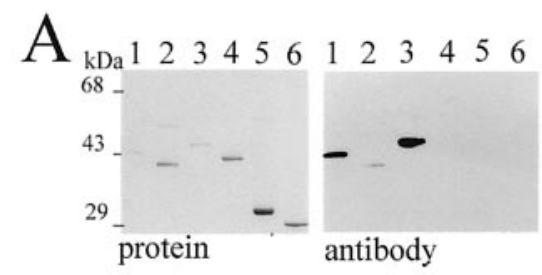

B

\section{RacGAP C-terminal Ab $\alpha 2 \mathrm{Ab}$}

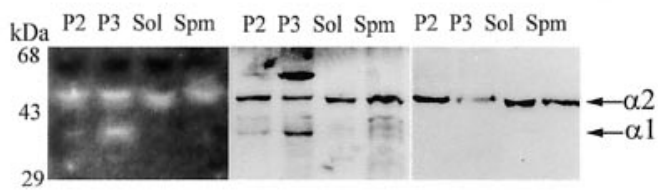

$\mathcal{C}$

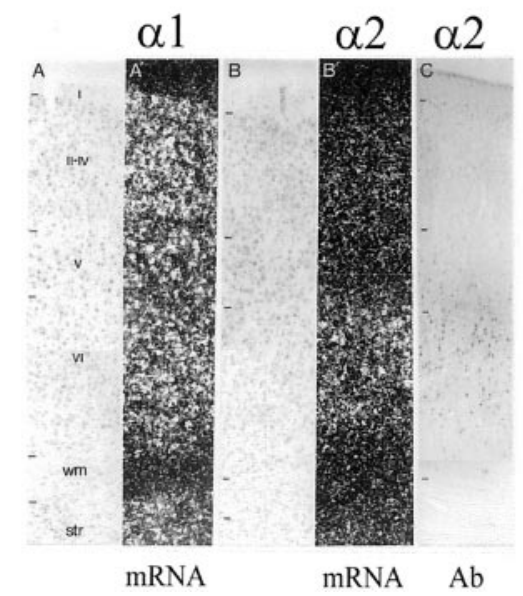

Figure 3. Subcellular distribution of $\alpha 2$-chimaerin in the brain. $A, \alpha 2$ chimaerin rabbit polyclonal antibody showed strong reactivity to the $\mathrm{N}$-terminal and was further purified by affinity chromatography on GST and recombinant $\alpha 1$-chimaerin. Western immunoblot analysis of recombinant $\alpha 2$-chimaerin constructs (shown stained with Coomassie blue) detected GST/ $\alpha 2$-chimaerin 1-160 (lane 1), GST/ $\alpha 2$-chimaerin 36-160 more weakly (lane 2), and full-length $\alpha 2$-chimaerin (lane 3), but not $\alpha 1$-chimaerin (lane 4), chimaerin C-terminal GAP domain (lane 5), or GST (lane 6). $B, \alpha 2$ - and $\alpha 1$-chimaerin protein are distributed in different subcellular fractions in brain: $P 2$, mitochondrial, myelin pellet obtained after centrifugation at $12,000 \times g$ for $10 \mathrm{~min} ; P 3$, microsomal pellet after centrifugation at $100,000 \times g$ for $1 \mathrm{hr}$; Sol, cytosolic fraction $(100,000 \times$ $g$ supernatant); Spm, synaptic plasma membranes purified from P2 fraction. RacGAP activity was analyzed by GAP overlay assay (left panel) (Manser et al., 1992). White bands show the location of proteins with GAP activity detected as areas of increased hydrolysis of $\left[\gamma^{32} \mathrm{P}\right]-\mathrm{GTP}-\mathrm{Rac}$. Corresponding Western immunoblots blots were assayed with $\mathrm{C}$-terminal $\alpha 1$-chimaerin antibodies (Kozma et al., 1996) (middle panel) or $\alpha 2$ chimaerin antibodies (right panel). The positions of $\alpha 2$-chimaerin (45 $\mathrm{kDa}$ ) and $\alpha 1$-chimaerin ( $38 \mathrm{kDa}$ ) are indicated by arrows. $C$, Comparison of $\alpha 1$ - and $\alpha 2$-chimaerin mRNA expression in cortical layers and corresponding $\alpha 2$-chimaerin immunoreactivity show the specificity of the antibody for the $\alpha 2$-chimaerin isoform in brain sections. $C, A, A^{\prime}$, Adult distribution of $\alpha 1$-chimaerin mRNA [counterstaining $(A)$ and in situ hybridization $\left(A^{\prime}\right)\left(\alpha 1\right.$ mRNA)]; $B, B^{\prime}$, distribution of $\alpha 2$-chimaerin at P17 [counterstaining $(B)$ and in situ hybridization $\left(B^{\prime}\right)(\alpha 2$ mRNA); $C$, $\alpha 2$-chimaerin immunocytochemistry]. I-VI, Cortical lamina; $w m$, white matter; str, striatum $(\alpha 2 \mathrm{Ab})$.

length were synthesized with comparable efficiency in an in vitro transcription-translation assay (data not shown) and in transfected cells. In transiently transfected COS-7 cells, $\alpha 2$-chimaerin was predominantly soluble with only small amounts in the pellet fraction after $0.5 \%$ Triton X-100 extraction (Fig. 5C). In contrast, $\alpha 1$-chimaerin was particulate (Kozma et al., 1996) (Fig. 5C). 


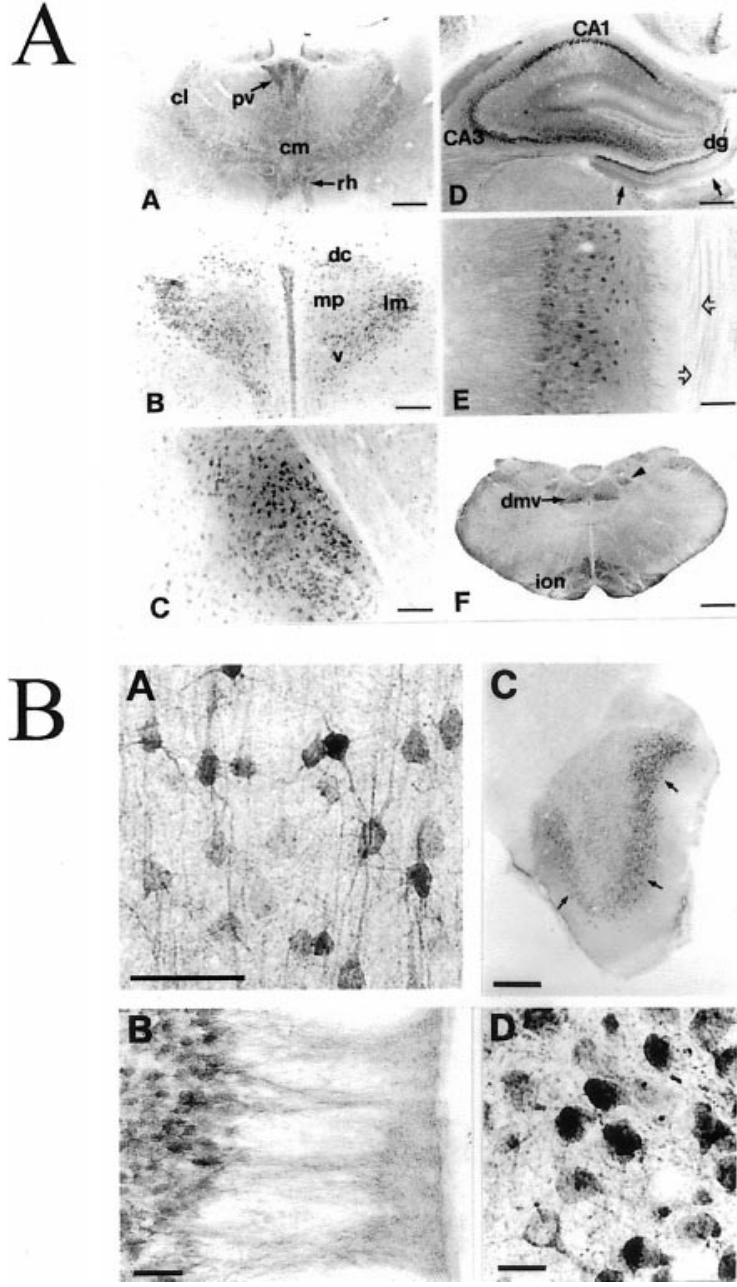

Figure 4. $\alpha 2$-chimaerin immunoreactivity in adult brain. $A$, In the thalamus $\left(A_{A}\right), \alpha 2$-chimaerin immunoreactivity was restricted to a subpopulation of cells, including the centrolateral $(\mathrm{cl})$ and centromedial $(\mathrm{cm})$ intralaminar nuclei and the midline paraventricular $(p v)$ and rhomboid $(r h)$ nuclei. Scale bar, $500 \mu \mathrm{m} . A_{B}$, Cells in the dorsal cap $(d c)$, lateromedial $(\operatorname{lm})$, and ventral $(v)$ portions of the paraventricular hypothalamic nucleus are immunoreactive in contrast with the light staining in the medial parvocellular $(\mathrm{mp})$ subdivision. Scale bar, $200 \mu \mathrm{m}$. $A_{C}$, Cells of the claustrum stain more strongly for $\alpha 2$-chimaerin compared with cells in adjoining cortex and striatum. Scale bar, $100 \mu \mathrm{m}$. $A_{D}$, In the hippocampal formation, $\alpha 2$-chimaerin immunoreactivity is marked in the CA1 and CA3 pyramidal cell and dentate gyrus $(d g)$ granule cell layers. Dendritic processes are clearly labeled in the stratum radiatum. A fine particulate staining is present in the stratum lacunosum moleculare and the outer two-thirds of the dentate gyrus molecular layer (arrows). Scale bar, 400 $\mu \mathrm{m} . A_{E}$, A higher power photomicrograph of the hippocampal formation at a more posterior level than $A_{D}$ shows staining of dendrites in the stratum radiatum and axons in the adjacent internal capsule (open arrows). Scale bar, $100 \mu \mathrm{m} . A_{F}$, In the medulla, immunoreactivity is localized to cells within the dorsal motor nucleus of the vagus nerve and inferior olivary complex. Some fiber tracts including the tractus solitarius (arrowhead) are also stained. Scale bar, $675 \mu \mathrm{m} . B$, $\alpha 2$-Chimaerin immunoreactivity in cortical regions at higher resolution shows layer V Ia of the cerebral cortex contains many darkly stained neurons and another population of moderately stained neurons $\left(B_{A}\right)$. Scale bar, $50 \mu \mathrm{m}$. $B_{B}$, In the retrosplenial granular cortex, neurons in layer II and their dendritic processes, which bundle in a characteristic manner, are stained. Scale bar, $50 \mu \mathrm{m} . B_{C}$, Immunoreactive neurons in the entorhinal cortex are found in both medial and lateral aspects. Most darkly stained neurons are located in layers II and III. Scale bar, $675 \mu \mathrm{m}$. $B_{D}$, A high-power photomicrograph of cells in the entorhinal cortex shows the granular nature of the labeling that is localized to the perikaryal cytoplasm and processes but is excluded from the nucleus. Scale bar, $20 \mu \mathrm{m}$.
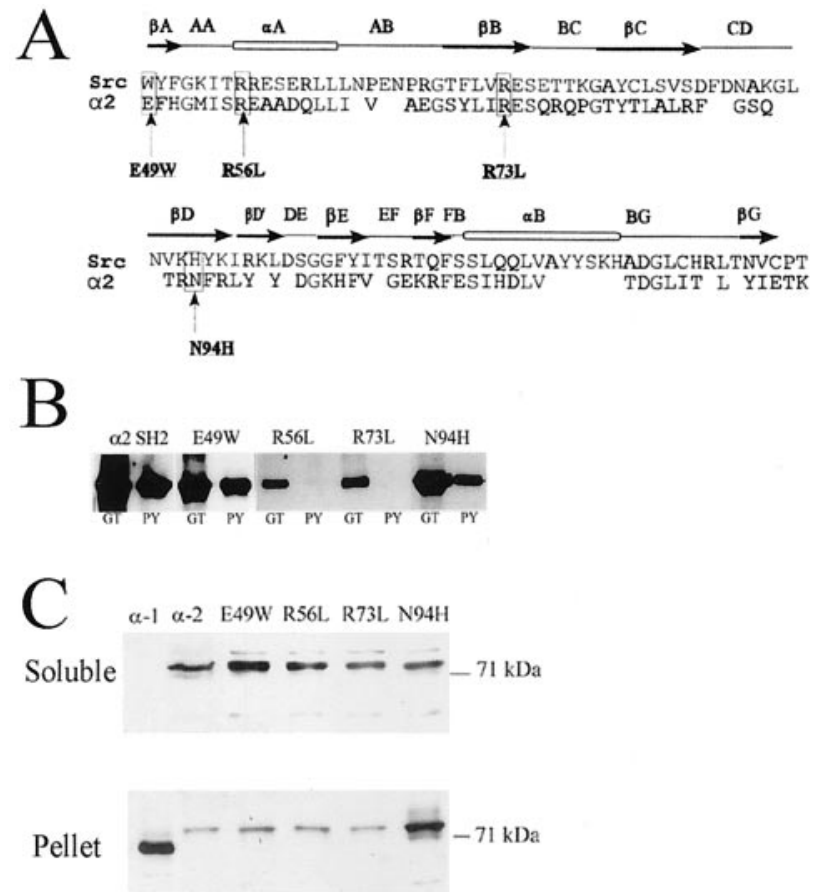

$\mathrm{D}$
$\begin{array}{ll}\mathrm{N} 1 \mathrm{E}-115 & \alpha 2 \\ \text { Sol MemCsk } & \text { Sol MemCsk }\end{array}$ $45 \mathrm{kDa}$ $\longrightarrow$

HAv Sol Mem Csk Sol Mem Csk $38 \mathrm{kDa}$ a
Sol

HAv $\alpha 2.6 \propto 2.7 \propto 2.8 \propto 2.22$

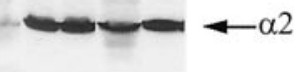

Csk

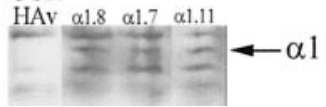

Figure 5. $\alpha 2$-chimaerin $\mathrm{SH} 2$ domain mutations and their effect on protein distribution in transfected cells. A, Alignment of chimaerin $\mathrm{SH} 2$ domain with $\mathrm{Src} \mathrm{SH} 2$ domain. Notation above the alignment refers to SH2 domain secondary structure (Waksman et al., 1993). Mutations were made at positions equivalent to Src $\beta \mathrm{A} 1, \alpha \mathrm{A} 2, \beta \mathrm{B} 5$, and $\beta \mathrm{D} 4$, residues likely to be involved in phosphopeptide interaction. $B$, Effect of $\mathrm{SH} 2$ domain mutations on binding to phosphotyrosine-agarose. Chimaerin SH2 domain and four SH2 domain mutants, E49W, R56L, R73L, and $\mathrm{N} 94 \mathrm{H}$, expressed as GST fusion proteins were bound to either glutathione-agarose $(G T)$ or phosphotyrosine-agarose $(P Y)$ columns eluted in SDS Laemmli buffer and analyzed by Western immunoblotting with $\alpha 2$-chimaerin antibody. $C$, Distribution of chimaerin isoforms and $\mathrm{SH} 2$ domain mutants. COS-7 cells were transiently transfected with GFP $/ \alpha 1$-chimaerin, GFP $/ \alpha 2$-chimaerin, GFP $/ \alpha 2$-chimaerin E49W, GFP/ $\alpha 2$-chimaerin R56L, GFP/ $\alpha 2$-chimaerin $\mathrm{R} 73 \mathrm{~L}$, or $\mathrm{GFP} / \alpha 2$-chimaerin N94H. Soluble and pellet fractions were analyzed by Western immunoblotting with anti-GFP monoclonal antibody (Clontech). Similar results were obtained in experiments with transiently transfected HA-tagged constructs in place of GFP. $D$, Permanent cell lines overexpressing $\alpha 2$ chimaerin or $\alpha 1$-chimaerin were fractionated into soluble $(\mathrm{Sol})$, solubilized membrane (Mem), and cytoskeletal (Csk) fractions. They were subject to Western immunoblotting using anti $\alpha 2$-chimaerin polyclonal antibodies to detect $\alpha 2$-chimaerin or anti-HA monoclonal antibody for $\alpha 1$-chimaerin. Soluble fractions from a series of $\alpha 2$-chimaerin lines $(\mathrm{Sol})$ and cytoskeletal fractions from a series of $\alpha 1$-chimaerin lines (Csk) are also shown. The positions of $\alpha 2-(45 \mathrm{kDa})$ and $\alpha 1$-chimaerin $(38 \mathrm{kDa})$ are indicated (arrows). Fractions from parent N1E115 cells and empty vector containing cells $(H A v)$ are also shown.

Cotransfection with Rac1 V12, Cdc42 V12, or RhoA V14, which became particulate, did not alter the disposition of $\alpha 2$-chimaerin (data not shown). The $\alpha 2$-chimaerin SH2 domain mutants E49W, R56L, and R73L were all predominantly soluble (Fig. 5C), 
whereas the $\mathrm{N} 94 \mathrm{H}$ mutant partitioned mainly in the particulate fraction (when expressed either as a GFP fusion protein or with an HA 10 amino acid residue tag).

Permanent chimaerin-expressing neuroblastoma N1E-115 cell lines were established that expressed either full-length $\alpha 1$ chimaerin $(38 \mathrm{kDa})$ or $\alpha 2$-chimaerin $(45 \mathrm{kDa})$ (Fig. $5 D)$. In several cell lines, $\alpha 2$-chimaerin was expressed at $>20$-fold higher levels than endogenous $\alpha 2$-chimaerin (Fig. $5 D$ ). $\alpha 2$-chimaerin was predominantly soluble with some membrane-associated (Fig. 5D). Endogenous $\alpha 1$-chimaerin was not detected (data not shown) but transfected HA-tagged $\alpha 1$-chimaerin was in the insoluble fraction and was cytoskeleton-associated (Fig. 5D). These subcellular distributions paralleled those of brain preparations, where $\alpha 2$ chimaerin was cytosolic and in membrane fractions (Hall et al., 1993) (Fig. 3B), whereas $\alpha 1$-chimaerin was absent from cytosol and was restricted to microsomal and other membrane fractions (Fig. 3B).

\section{Differential effects of $\alpha 2$ - and $\alpha 1$-chimaerins on morphology of neuroblastoma cells}

Neuroblastoma cells transiently transfected with $\alpha 2$-chimaerin produced multiple neurites when stimulated by low serum when grown on poly-lysine, and the protein was present throughout the cell body and neurites (Fig. 6). A similar phenotype and protein distribution was generated by E49W, R56L, and R73L $\alpha 2$ chimaerin mutants. All the cells also displayed peripheral actin microspikes and ruffles, (the latter especially along the processes of cells expressing the R56L and R73L mutants) (Fig. 6). In contrast, cells transfected with $\alpha 2$-chimaerin $\mathrm{N} 94 \mathrm{H}$ were rounded, and little neurite formation occurred; protein appeared punctate and membrane-associated. The phenotype and protein distribution resembled those of $\alpha 1$-chimaerin-transfected cells, as did the presence of dense F-actin. Inactivation of the GAP domain of $\alpha 2$-chimaerin by mutation of the conserved catalytically important RhoGAP arginine residue (R304 in chimaerin) (Barrett et al., 1997; Leonard et al., 1998; Taylor et al., 1999) resulted in similar protein distribution and morphology to wildtype $\alpha 2$-chimaerin, except that ruffles and neurites were more pronounced (Fig. 6), indicative of enhanced Rac signaling. Expression of $\alpha 2$-chimaerin $\mathrm{N} 94 \mathrm{H}$ with inactivating mutations of the GAP domain ( $\alpha 2$-chimaerin N94H,R304G or $\alpha 2$ chimaerinN94H, $\Delta 303-305)$ altered the morphological effects of the $\mathrm{N} 94 \mathrm{H}$ mutant, promoting outgrowth, rather than cell rounding, without affecting its particulate disposition (Fig. 6).

In the permanent cell lines overexpressing either $\alpha 2$ - or $\alpha 1$ chimaerin grown on poly-lysine their distinctive morphology was consistent with a potentiation of $\mathrm{Cdc} 42$ and/or Rac1 signaling. $\alpha 2$-chimaerin overexpressing cells were flattened with peripheral microspikes and ruffles, a phenotype indicative of both Rac1 and Cdc42 activation (Fig. $7 A_{e-g}$ ), and neurites in the presence or absence of serum $(12-16 \%$ of cells with neurites $>2 \times$ cell body diameter) (Fig. $7 B$ ). The neurites were immunoreactive to $\mathrm{p} 35$, the neuronal regulator of cdk5 involved in neurite outgrowth (Nikolic et al., 1996), and to neurofilament antibodies (Fig. 7A ${ }_{h-j}$ ). Some cells (40\%) were large with a diameter of 50-100 $\mu \mathrm{m}$ (Fig. $7 B)$. As with transient transfectants, $\alpha 2$-chimaerin was present throughout the cell, in neurites and growth cones (Fig. $7 A_{e}$ ). The $\alpha 1$-chimaerin-expressing cell lines were characterized by a preponderance $(70 \%)$ of small round cells with peripheral microspikes and dense F-actin within the cell body, characteristic of morphology generated by $\mathrm{Cdc} 42$ activation (Fig. 7). Neurite formation was negligible compared with $\alpha 2$-chimaerin-expressing or

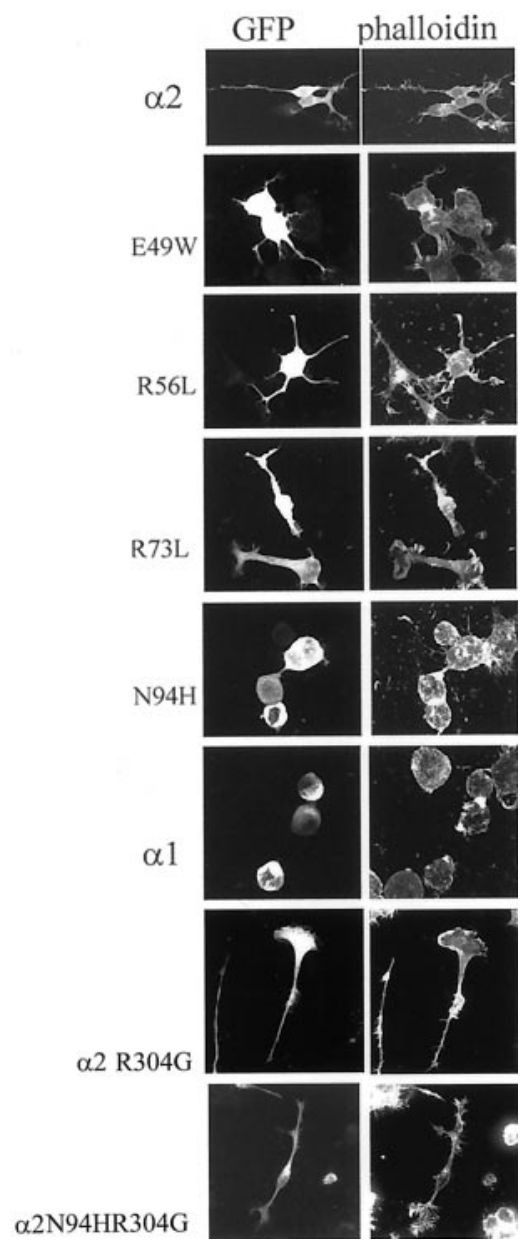

Figure 6. Transient expression of $\alpha 2$-chimaerin, its $\mathrm{SH} 2$ and GAP domain mutants, and $\alpha 1$-chimaerin in N1E-115 neuroblastoma cells. Cells plated on poly-lysine were transfected with pXJ40-GFP- $\alpha 2$-chimaerin, $\mathrm{SH} 2$ domain mutants E49W, R56L, R73L, N94H, $\alpha 1$-chimaerin, $\alpha 2$-chimaerin GAP domain mutant $\alpha 2 \mathrm{R} 304 \mathrm{G}$, or $\alpha 2 \mathrm{~N} 94 \mathrm{HR} 304 \mathrm{G} \mathrm{SH} / \mathrm{GAP}$ double mutant (or GFP; data not shown). Transfectants were cultured in DMEM and 5\% FCS for $24 \mathrm{hr}$, stained with phalloidin, and analyzed by confocal microscopy. GFP fluorescence and corresponding F-actin are shown.

control cells, even when cells were stimulated by serum withdrawal (Fig. 7B). Further differentiation of $\alpha 2$-chimaerin cell lines (but not $\alpha 1$-chimaerin or control cell lines) could be induced by treatment with dibutyryl cAMP (1 mM) for $24 \mathrm{hr}$. Under these conditions, $38 \%$ of $\alpha 2$-chimaerin-expressing cells formed neurites $>2$ cell diameters, which stained strongly with neurofilament antibody (data not shown), whereas only $3-6 \%$ of $\alpha 1$-chimaerin or control cells formed neurites.

Permanent $\alpha 2$-chimaerin-expressing cell lines, which produced some neurites whether or not exposed to serum, were then transfected with dominant negative mutants of Cdc42 and Rac1. When transiently transfected with GFP-Rac1 N17, cells (60\%) displayed numerous large, elaborate filopodial extensions but almost no ruffles (Fig. $8 a, b$ ). The peripheral changes indicate that $\mathrm{Cdc} 42$ activation still occurred, whereas Rac1 N17 interfered with production of ruffles. GFP-Cdc42 N17 transfection led to enhanced cell ruffling and spread flat cells, typical of a Rac1-phenotype, but few cells exhibited peripheral microspikes (Fig. 8a,c). In both cases neurite formation was reduced (to 3-4\%, compared with $12 \%$ in the untransfected cell line) (Figs. 7, 8). These results are consistent with $\alpha 2$-chimaerin expression stimulating Cdc42- and 

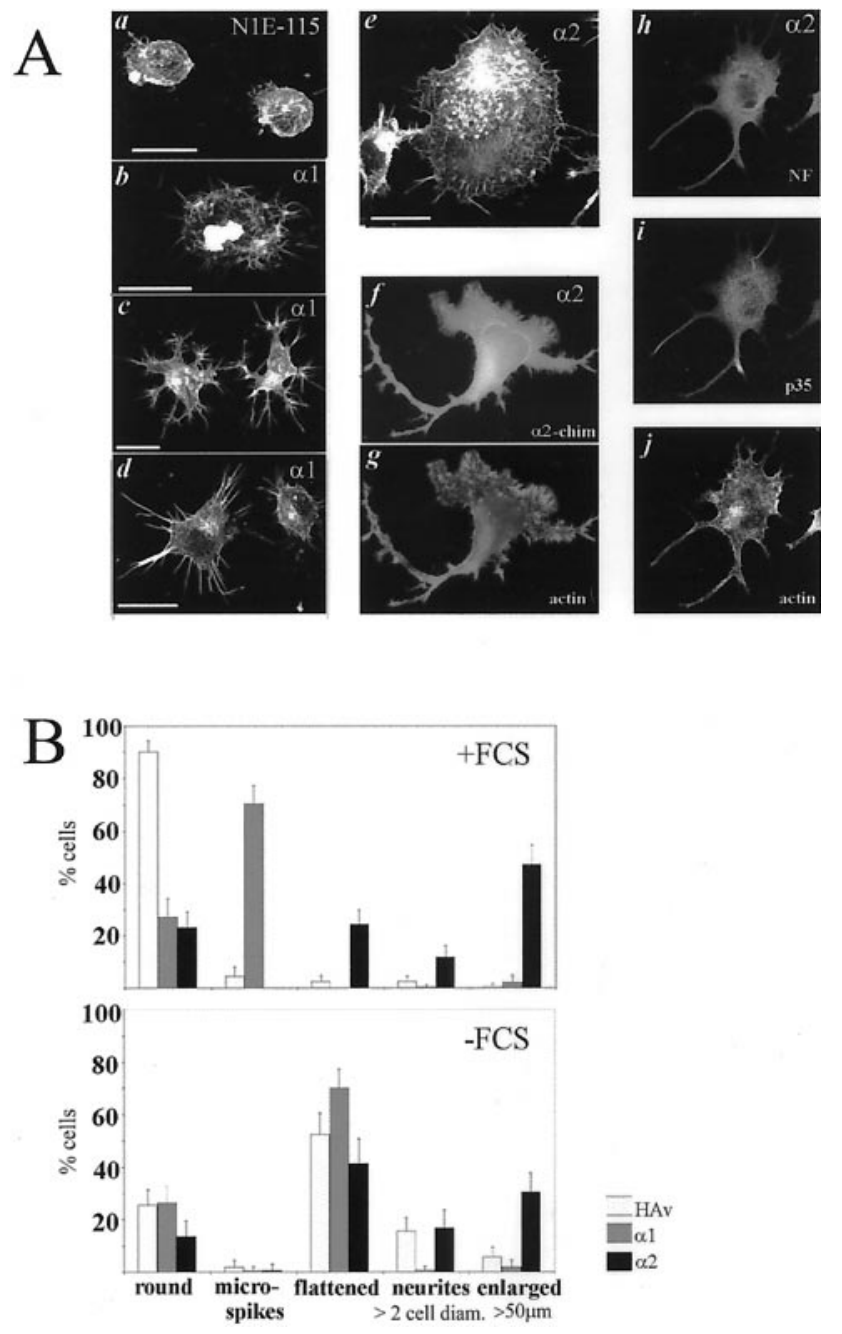

Figure 7. Permanent $\alpha 1$ - and $\alpha 2$-chimaerin N1E-115 cell lines show differences in morphology. $A, \mathrm{~N} 1 \mathrm{E}-115$ cell lines overexpressing $\alpha 1$ chimaerin $(b-d)$ or $\alpha 2$-chimaerin $(e-j)$ were grown in DMEM, $10 \% \mathrm{FCS}$, fixed, subjected to immunocytochemistry and/or phalloidin staining, and analyzed by confocal $(b-e, h-j)$ or fluorescence microscopy $(f, g)$. Parent N1E-115 cells are shown for comparison $(a)$. Phalloidin staining of F-actin $(a-e, g, j)$, anti- $\alpha 2$-chimaerin antibody staining are shown in $f$, an $\alpha 2$-chimaerin expressing cell $(h-j)$ stained with anti-neurofilament p68 (Sigma) in $h$, anti-p35 (cdk5 neuronal activator) (Santa Cruz Biotechnology, Santa Cruz, CA) in $i$, and phalloidin in $j$. Scale bar, $25 \mu \mathrm{m}$. B, Quantification of cell morphologies in the presence or absence of FCS. $\alpha 1$-chimaerin, $\alpha 2$-chimaerin N1E-115 cell lines, and vector-transfected N1E-115 control cell line $(H A v)$ grown in DMEM in the presence or absence of $10 \%$ FCS were counted in five morphology categories; round, flattened, enlarged cells $>50 \mu \mathrm{m}$, cells with peripheral microspikes, and cells with neurites $>2 \times$ cell diameter in length. We counted 600-1000 cells per category. Error bars indicate SD.

Rac1-requiring morphological pathways underlying neurite outgrowth. Furthermore, transient transfection (24 hr) of $\alpha 2$ chimaerin cell lines with GFP-chimaerin N94H SH2 domain mutant altered the morphology to form rounded cells and prevented neurite outgrowth (Fig. 8a,h), indicating that the $\mathrm{SH} 2$ domain has an important regulatory role. In stable $\alpha 1$-chimaerinexpressing cell lines, the effects of Rac1 N17 and Cdc42 N17 were less evident (Fig. 8c,d,i), except when cells were plated on laminin (Fig. $8 e, f, j$ ). Growth on laminin results in integrin-mediated stimulation of both Cdc42- and Rac1-type effects in N1E-115 cells (Sarner et al., 2000).

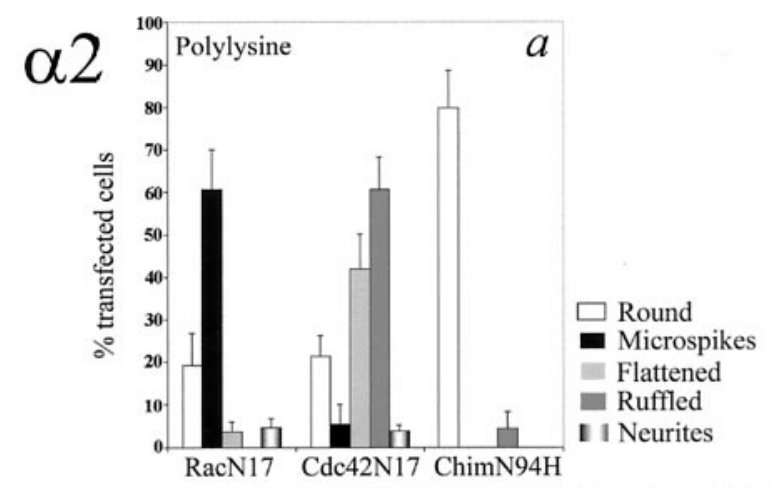

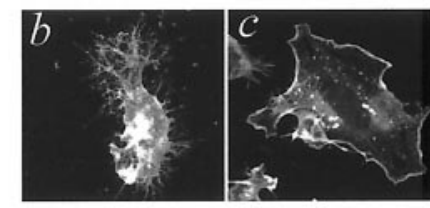

RacN17

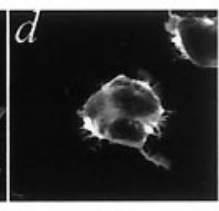

Chimaerin $\mathrm{N} 94 \mathrm{H}$

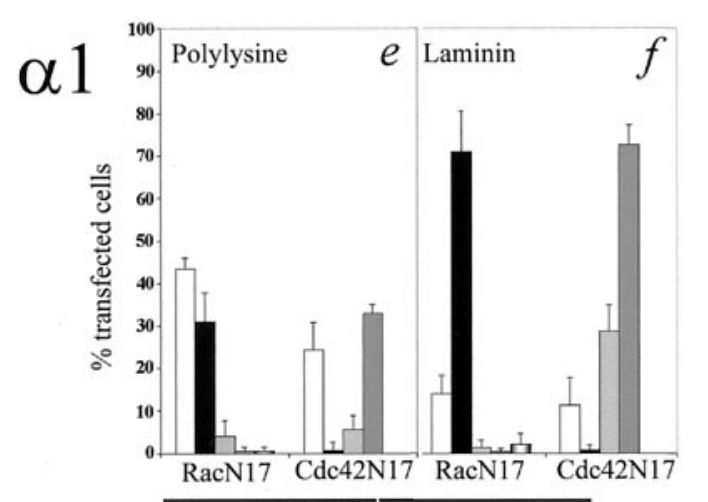

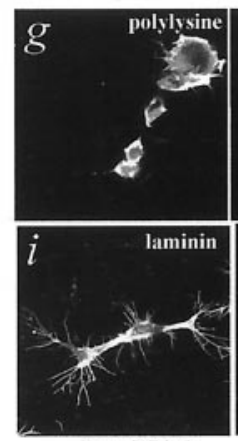

RacN17
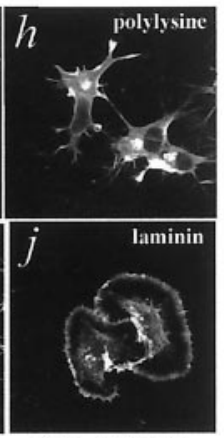

Cdc42N17

Figure 8. Effects of Rac1 N17 and Cdc42 N17 (and chimaerin N94H) on chimaerin cell lines. $A$, Permanent $\alpha 2$-chimaerin $(b-d)$ and $\alpha 1$-chimaerin cell lines $(g-j)$ were transiently transfected with GFP-Rac1 N17 $(b, g, i)$ or HA-Cdc42 N17 $(c, h, j)$ and stained with phalloidin and (where appropriate) anti-HA antibody. Cells were plated on poly-lysine $(b-h)$ or laminin $(i, j)$. Permanent $\alpha 2$-chimaerin cell lines transiently transfected with GFP-chimaerin N94H were phalloidin-stained $(d)$. Morphology of permanent $\alpha 2$-chimaerin cells plated on poly-lysine $(a)$ and permanent $\alpha 1$-chimaerin-expressing cell lines plated on poly-lysine $(e)$ or laminin $(f)$ and transiently transfected with GFP-tagged constructs, as indicated, were quantitated in five morphology categories: round (white columns), microspikes (black columns), flattened (light gray columns), ruffled (dark gray columns), and with neurites $>2$ cell diameter (striped columns) as a percentage of (GFP-expressing) transfected cells.

The effects of Rac1 N17 or Cdc42 N17 on $\alpha 2$-chimaerin expressing cells (the formation of microspikes and ruffles, respectively) were similar on laminin or poly-lysine substrates.

The effects of $\alpha 2$-chimaerin and $\mathrm{SH} 2$ domain mutants was next 


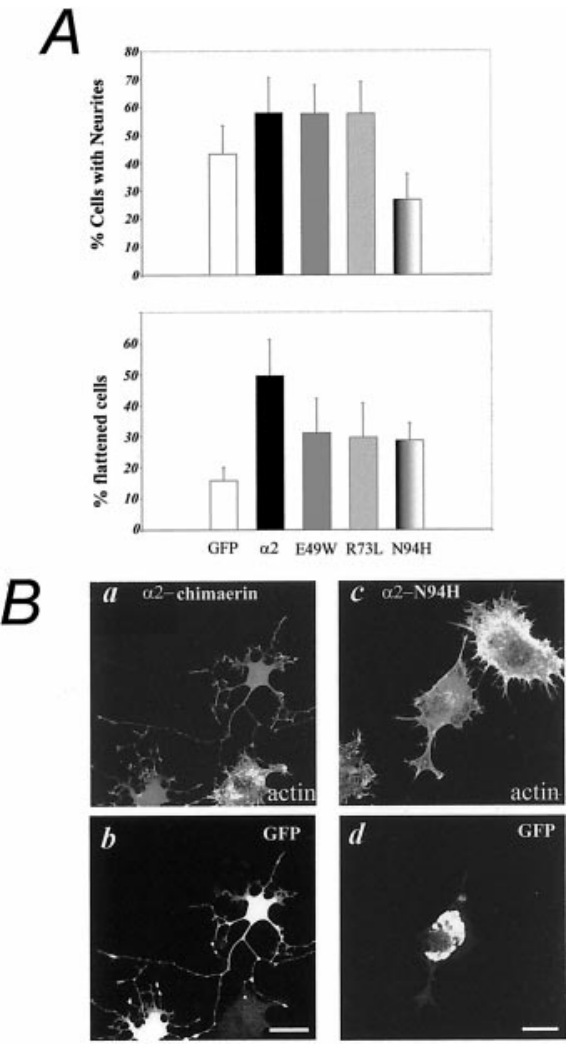

Figure 9. A, Top, Quantification of NGF-stimulated PC12 cells with neurites after transient transfection with GFP (white columns), GFP- $\alpha 2-$ chimaerin (black columns), GFP- $\alpha 2$-chimaerin E49W (dark gray columns), GFP- $\alpha 2$-chimaerin R73L (light gray columns), or GFP- $\alpha 2$ chimaerin $\mathrm{N} 94 \mathrm{H}$ (striped columns) and NGF treatment $(100 \mathrm{ng} / \mathrm{ml})$ for 24 hr. We counted 250 cells per category. NGF treatment for 48-60 hr gave similar results. Error bars indicate SD. Chimaerin N94H transfectants showed significant differences from wild-type $(p<0.003)$, E49W ( $p<$ $0.01)$, R73L $(p<0.0001)$, and GFP transfectants $(p<0.05)$. Chimaerin E49W and R73L also showed significant differences from GFP transfectants ( $p<0.05, p<0.01$; Student's $t$ test). A, Bottom, Cells expressing GFP- $\alpha 2$-chimaerin were more spread and flattened than GFP-expressing cells $(p<0.001)$. Error bars indicate SEM from three experiments. $B$, Transient PC12 cell transfectants stimulated with NGF for $60 \mathrm{hr}$ expressing GFP- $\alpha 2$-chimaerin (b) (GFP) and phalloidin-stained (actin) in $a$ shows chimaerin is present throughout neurites. Expression of $\alpha 2-$ chimaerin $\mathrm{N} 94 \mathrm{H}$ ( $d$, GFP; $c$, phalloidin-stained) led to altered cell morphology $(c)$ and protein distribution $(d)$.

investigated in PC12 cells stimulated with NGF to induce neurites, in which phosphotyrosine-SH2 domain interactions are involved. Transient transfection of GFP- $\alpha 2$-chimaerin in NGF-stimulated cells led to a significant increase in spread and flattened cells and a variable effect on neurites (Fig. 9A). $\alpha 2$-chimaerin E49W and R73L mutants produced minor increases in formation of neurites compared with GFPtransfected cells (Fig. 9A), although subtle effects on morphology cannot be excluded. $\alpha 2$-chimaerin (and E49W and R73L mutants) was present throughout the neurites (Fig. 9B $B_{b}$ ). As in neuroblastoma N1E-115 cells, the N94H SH2 domain mutation altered the protein distribution and cell morphology (Fig. $\left.9 B_{c, d}\right)$ and also inhibited NGF-induced neurite formation in NGF-stimulated PC12 cells (Fig. 9A).

\section{DISCUSSION}

We have found that $\alpha 2$-chimerin, a neuronal regulator of the Rho GTPase family, is developmentally expressed in the CNS in a manner suggesting a role in neuronal differentiation. Transfection with $\alpha 2$-chimaerin led to N1E-115 neuroblastoma cells exhibiting morphological effects including neurite formation, which was eliminated by a mutation of the $\mathrm{SH} 2$ domain. The presence of an $\mathrm{SH} 2$ domain is important for the morphological function of $\alpha 2$-chimaerin.

\section{Developmental expression of $\alpha 2$-chimaerin mRNA}

The caudorostral developmental pattern of expression of its mRNA and its substantial increase in postmitotic but not proliferative neurons indicate an involvement of $\alpha 2$-chimaerin in early neuronal developmental processes, which include morphological differentiation. A similar spatiotemporal pattern of expression in postmitotic neurons has been reported for $\mathrm{Cdk} 5 / \mathrm{p} 35$ (Tsai et al., 1993; Delalle et al., 1997; Zheng et al., 1998) and Crmp-2 (Minturn et al., 1995a,b; Wang and Strittmatter, 1996), which are implicated in neuronal outgrowth or axonal guidance (Goshima et al., 1995; Nikolic et al., 1996). Cdk5 with its neuronal specific regulator p35 functions as a Rac effector (Nikolic et al., 1998), and mice lacking p35 display defects of cortical lamination arising from disruption of normal cell migration (Chae et al., 1997). Its expression pattern in the cortical layers suggests $\alpha 2$-chimaerin may also have a role in elaboration of processes or neuronal maturation. In keeping with this suggestion, $\alpha 2$-chimaerin has been found to interact with Crmp-2 (Teo, 1994; Ferrari, 1999) (our unpublished data). Chimaerin also interacts with p35 (R. Qi and J. Wang, personal communication) (data not shown).

\section{$\alpha 2$-chimaerin mRNA expression in adult brain}

In the adult, the expression pattern of $\alpha 2$-chimaerin mRNA is similar to that of the $\mathrm{m} 3$ muscarinic receptor mRNA in many regions (Buckley et al., 1988). In the cerebral cortex, both mRNAs are expressed in a laminar manner with peaks in superficial layers and layer VI. Consistent with the possible relationship between $\alpha 2$-chimaerin and the cholinergic system in the adult, the maturation of cholinergic innervation occurs after day 7 (Johnston and Coyle, 1980). Although undetectable before E16, the much more abundant $\alpha 1$-chimaerin mRNA is expressed highly in regions involved in learning and memory including the cerebral cortex, hippocampal formation, and cerebellar Purkinje cells (Table 1) (Lim et al., 1992).

\section{Neuronal expression of $\alpha 2$-chimaerin protein}

$\alpha 2$-chimaerin immunoreactivity is found throughout the entire neuron, except the nucleus, but not glia. The punctate appearance of labeling on cell bodies, dendrites, and in the neuropil perhaps reflects its localization in structures associated with synapses. Mossy fiber terminals in hippocampal region CA3 originating from cells in the dentate gyrus are clearly stained. A dramatic staining of the outer two-thirds of the molecular layer of the dentate gyrus is also observed. This pattern of labeling is likely to be produced by staining of the terminals of perforant pathway afferents arising from the neurons of the entorhinal cortex, in which $\alpha 2$-chimaerin is enriched. Intracellularly, $\alpha 2$-chimaerin is localized in the cytosolic fraction, as well as plasma membrane and microsomal fractions. This localization contrasts with that of the wholly particulate $\alpha 1$-chimaerin.

\section{A possible function of $\alpha 2$-chimaerin in neuronal differentiation}

To determine the role of $\alpha 2$-chimaerin involving its $\mathrm{SH} 2$ domain, we have examined the morphological effects of overexpression of both $\alpha 1$ - and $\alpha 2$-chimaerin in transiently and permanently trans- 
fected N1E-115 neuroblastoma cells and also in NGF-stimulated PC12 cells. These gave essentially the same result, that $\alpha 2$ chimaerin potentiates neurite formation with the $\mathrm{SH} 2$ domain being an important component.

Serum contains factors such as lysophosphatidic acid, which activate RhoA signaling pathways; in its presence N1E-115 cells are rounded and lack neurites indicative of a RhoA-phenotype. Withdrawal of serum (i.e., loss of RhoA activation) or expression of dominant-negative RhoA N19 can promote neurite outgrowth. Outgrowth is better on laminin than poly-lysine consistent with integrin activation of Cdc42-Rac pathways (Kozma et al., 1997; Sarner et al., 2000). Cells permanently overexpressing $\alpha 2$ chimaerin when grown on poly-lysine become flattened, with ruffles and microspikes, and form neurites, whether or not they are stimulated by serum withdrawal. The transient expression of $\mathrm{Cdc} 42$ N17 interferes with formation of peripheral microspikes but not ruffling (a Rac1-type effect), transient expression of Rac1 N17 interferes with ruffling but not microspike formation (a Cdc42-type effect), and both led to a reduction in neurites. Cells overexpressing $\alpha 1$-chimaerin showed microspike formation (blocked by expression of dominant-negative $\mathrm{Cdc} 42 \mathrm{~N} 17$ ) but not ruffles or neurites. It appears that $\alpha 2$ - is more effective than $\alpha 1$-chimaerin in stimulating morphological changes associated with formation of neurites.

These results indicate that $\alpha 2$-chimaerin enhances $\mathrm{Cdc} 42$ and Rac1 signaling pathways, both of which are required for neurite outgrowth. $\alpha 1$-chimaerin expression results in net increased activation of $\mathrm{Cdc} 42$ pathways. Possibly, $\alpha 1$-chimaerin expression enhances activation of both $\mathrm{Cdc} 42$ and Rac1 pathways, but Rac1 downregulation also occurs. [Both types of cell lines were more adhesive than N1E-115 control cells with or without empty vector, requiring trypsin for detachment during culturing (data not shown)]. The distinct morphologies of neuroblastoma cells transiently transfected with $\alpha 1$ - and $\alpha 2$-chimaerin is also consistent with differences in Rac1 regulation. Although the $\mathrm{SH} 2$ domain confers increased GAP activity to $\alpha 2$-chimaerin in vitro, RacGAP activity in chimaerin cell lines was not different in the various subcellular fractions, except for an increase in the cytoskeletal fraction of cells overexpressing either isoform compared with control N1E-115 or vector-containing cells (data not shown). The cytoskeletal increase may reflect a need for increased usage or turnover of Rac1 in cytoskeleton-based morphological changes. Although these assays do not distinguish between chimaerin and other RacGAPs, they indicate that the differences in morphological functions of $\alpha 1$ - and $\alpha 2$-chimaerin do not arise solely from RacGAP activities. Although chimaerin GAP domain alone will downregulate the morphological activities of Rac1, full-length $\alpha 1$ chimaerin induces the formation of lamellipodia and filopodia in fibroblasts and neuroblastomas, an effect enhanced by an inactivating mutation of the GAP domain (Kozma et al., 1996) (data not shown). The enhanced formation of neurites and ruffles by $\alpha 2$ chimaerin GAP-defective mutants, which retain GTPase binding ability (Ahmed et al., 1994; Leonard et al., 1998), provides further evidence that $\alpha 2$-chimaerin can promote as well as downregulate Rac signaling. Protein-protein interactions in vivo involving chimaerin SH2 domain may affect GAP activity and/or GTPase activation levels. Interestingly, regulation of Cdc42 PSGAP activity by tyrosine kinase PYK2, which interacts with its $\mathrm{SH} 3$ domain, can lead to Cdc42 activation (Ren et al., 2001).

There is a direct relationship between the different morphological activities of the two $\alpha$-chimaerin isoforms and their cellular compartmentation. Clearly, the SH2 domain confers differential functions to the $\alpha 2$ isoform, because the effects and compartmen- tation of the $\alpha 2-\mathrm{N} 94 \mathrm{H}$ mutant resemble those of $\alpha 1$-chimaerin. The formation of neurites in permanent $\alpha 2$-chimaerin cell lines, and also in NGF-stimulated PC12 cells, is inhibited by its expression. Interestingly, $\alpha 2$-chimaerin $\mathrm{N} 94 \mathrm{H} \mathrm{SH} 2$ no longer binds Crmp-2 (Ferrari, 1999), although in vitro phosphotyrosine binding is unaffected. Predicted chimaerin SH2 domain structure modeled on Grb-2 SH2 (Thornton et al., 1996) indicates that the N94H substitution could displace an aspartate residue (D60), locally altering surface charge in the region adjacent to the phosphotyrosine binding pocket, potentially disrupting target interactions. Relocation and/or lipid activation of GAP activity could be responsible for the morphological effects (cell rounding) of $\alpha 2$-chimaerin N94H SH2 in N1E-115 cells, because mutation of its GAP domain promoted microspikes and neurite outgrowth. GAP-inactive $\alpha 1$ chimaerin showed similar morphological effects to this $\alpha 2$ chimaerin SH2 GAP double mutant (data not shown). These results are consistent with a functional requirement for the diverse $\mathrm{N}$-terminals of $\alpha$-chimaerins in Rac regulation and morphology.

The limited effect of the chimaerin SH2 domain R73L mutant (which does not bind phosphotyrosine) on neurite outgrowth in PC12 cells suggests that chimaerin SH2 domain may not be a direct target of NGF-induced phosphotyrosine signaling. Although the atypical $\mathrm{SH} 2$ domain of $\alpha 2$-chimaerin will bind phosphoproteins (Hall et al., 1993) these remain unidentified. A wide variety of receptor tyrosine kinases are involved in neuronal differentiation and axonal guidance (O'Leary and Wilkinson, 1999). Ephrin-A5 induces growth cone collapse through activation of Rho GTPase signaling (and inactivation of Rac) (Wahl et al. 2000). Tyrosine kinase abl and receptor phosphatase Lar are involved in axiogenesis (Lanier and Gertler, 2000). Lar can interact with the Rho/Rac GEF Trio (Debant et al., 1996), a key factor in axon guidance (Newsome et al., 2000), providing a direct link to actin regulation. Rac GAP $\alpha 2$-chimaerin may link dynamic Rac1-dependent growth cone activity to guidance molecules or growth factor signaling through tyrosine kinases.

The high level of expression of $\alpha 2$-chimaerin implies a particular role in the entorhinal cortex, which is involved in memory and pathological change in Alzheimer's disease (Hyman et al., 1990). Interestingly, cleavage of p35 is increased in Alzheimer's disease, leading to altered subcellular disposition and disordered Cdk5 activity, perhaps contributing to pathology (Patrick et al., 1999). In $\alpha 2$-chimaerin-expressing cell lines, p35 colocalized with actin and could be coimmunoprecipitated with chimaerin (unpublished data). Our findings of a role for $\alpha 2$-chimaerin in neuronal differentiation and its interactions with p35 and Crmp-2 suggest an involvement in mechanisms underlying development and possibly also pathology of brain regions selectively affected in Alzheimer's disease.

\section{REFERENCES}

Ahmed S, Lee J, Wen L-P, Zhao Z, Ho J, Best A, Kozma R, Lim L (1994) Breakpoint cluster region gene product-related domain of $N$-chimaerin. J Biol Chem 269:17642-17648.

Barrett T, Xiao B, Dodson EJ, Dodson G, Ludbrook SB, Nurmahomed K, Gamblin SJ, Musacchio A, Smerdon SJ, Eccleston JF (1997) The structure of the GTPase activating domain from p50rhoGAP. Nature 385:458-461.

Bibbins KB, Boeuf H, Varmus HE (1993) Binding of the Src SH2 domain to phosphopeptides is determined by residues in both the $\mathrm{SH} 2$ domain and the phosphopeptides. Mol Cell Biol 13:7278-7287.

Bito H, Furuyashiki T, Ishihara H, Shibasaki Y, Ohashi K, Mizuno K, Maekawa M, Ishizaki T, Narumiya S (2000) A critical role for a Rho-associated kinase, P160Rock, in determining axon outgrowth in mammalian CNS neurons. Neuron 26:431-441.

Brandt SJ, Niedel JE, Bell RM, Young WS III (1987) Distinct patterns of expression of different protein kinase $\mathrm{C}$ mRNAs in rat tissues. Cell 49:57-63. 
Buckley NJ, Bonner TI, Brann MR (1988) Localization of a family of muscarinic receptor mRNAs in rat brain. J Neurosci 8:4646-4652.

Chae T, Kwon YT, Bronson R, Dikkes P, Li E, Tsai L-H (1997) Mice lacking p35, a neuronal specific activator of CDK5, display cortical lamination defects, seizures and adult lethality. Neuron 18:29-42.

Debant A, Serra-Pages C, Seipel K, O'Brien S, Tang M, Park SH, Streuli M (1996) The multidomain protein Trio binds the LAR transmembrane tyrosine phosphatase, contains a protein kinase domain, and has separate rac-specific and rho-specific guanine nucleotide exchange factor domains. Proc Natl Acad Sci USA 93:5466-5471.

Delalle I, Bhide PG, Caviness VS, Tsai LH (1997) Temporal and spatial patterns of expression of $\mathrm{p} 35$, a regulatory subunit of cyclin-dependent kinase 5, in the nervous system of the mouse. J Neurocytol 26:283-296.

Diekmann D, Brill S, Garrett MD, Totty N, Hsuan J, Monfries C, Hall C, Lim L, Hall A (1991) bcr encodes a GTPase activating protein for p21rac. Nature 351:400-402.

Ehler E, van Leeuwen F, Collard JG, Salinas PC (1997) Expression of Tiam-1 in the developing brain suggests a role for the Tiam-1-Rac signaling pathway in cell migration and neurite outgrowth. Mol Cell Neurosci 9:1-12.

Ferrari GM (1999) The interaction of the $\alpha 2$-chimaerin SH2 domain with target proteins, $\mathrm{PhD}$ thesis, University of London.

Goshima Y, Nakamura F, Strittmatter P, Strittmatter SM (1995) Collapsin-induced growth cone collapse mediated by an intracellular protein related to unc-33. Nature 376:509-514.

Hall C, Sin WC, Teo M, Michael GJ, Smith P, Dong JM, Lim HH, Manser E, Spurr NK, Jones TA, Lim L (1993) $\alpha 2$-Chimerin, an SH2containing GTPase-activating protein for the ras-related protein $\mathrm{p} 21^{\text {rac }}$ derived by alternate splicing of the human $N$-chimerin gene, is selectively expressed in brain regions and testis. Mol Cell Biol 13:4986-4998.

Hyman BT, Van Hoesen GW, Damasio AR (1990) Memory-related neural systems in Alzheimer's disease: an anatomic study. Neurology 40:1721-1730.

Jin Z, Strittmatter SM (1997) Rac1 mediates collapsin-1-induced growth cone collapse. J Neurosci 17:6256-6263.

Johnston M, Coyle J (1980) Ontogeny of neurochemical markers for noradrenergic, GABAergic and cholinergic neurons in neocortex lesioned with methylazoxymethanol acetate. J Neurochem 34:1429-1441.

Kozma R, Ahmed S, Best A, Lim L (1996) The GTPase-activating protein $\mathrm{N}$-chimaerin cooperates with $\mathrm{Rac} 1$ and $\mathrm{Cdc} 42 \mathrm{Hs}$ to induce the formation of lamellipodia and filopodia. Mol Cell Biol 16:5069-5080.

Kozma R, Sarner S, Ahmed S, Lim L (1997) Rho family GTPases and neuronal growth cone remodelling: relationship between increased complexity induced by $\mathrm{Cdc} 42 \mathrm{Hs}$, Rac1 and acetylcholine and collapse induced by RhoA and lysophosphatidic acid. Mol Cell Biol 17:1201-1211.

Kwon YT, Tsai LH (1998) A novel disruption of cortical development in p35(-/-) mice distinct from reeler. J Comp Neurol 395:510-522.

Lanier LM, Gertler FB (2000) Fom Abl to actin: Abl tyrosine kinase and associated proteins in growth cone motility. Curr Opin Neurobiol 10:80-87.

Lee T, Winter C, Marticke SS, Lee A, Luo L (2000) Essential roles of Drosophila RhoA in the regulation of neuroblast proliferation and dendritic but not axonal morphogenesis. Neuron 25:307-316.

Leonard DA, Lin R, Cerione RA, Manor D (1998) Biochemical studies of the mechanism of action of the Cdc42-GTPase activating protein. J Biol Chem 273:16210-16215.

Leung T, How BE, Manser E, Lim L (1993) Germ-cell beta-chimaerin, a new GTPase-activating protein for p21Rac, is specifically expressed during the acrosomal assembly stage in rat testis. J Biol Chem 268:3813-3816.

Leung T, How BE, Manser E, Lim L (1994) Cerebellar beta-2chimaerin, a GTPase-activating protein for p21 Ras-related Rac is specifically expressed in granule cells and has a unique N-terminal SH2 domain. J Biol Chem 269:12888-12892

Lim HH, Michael GJ, Smith P, Lim L, Hall C (1992) Developmental regulation and neuronal expression of the mRNA of rat $N$-chimaerin, a p21rac GAP: cDNA sequence. Biochem J 287:415-422.

Luo L, Hensch TK, Ackerman L, Barbel S, Jan LY, Jan YN (1996) Differential effects of the RacGTPase on Purkinje cell axons and dendritic trunks and spines. Nature 379:837-840.

Manser E, Leung T, Monfries C, Teo M, Hall C, Lim L (1992) Diversity and versatility of GTPase activating proteins for the p21rho subfamily of ras $\mathrm{G}$ proteins detected by a novel overlay assay. J Biol Chem 267:16025-16028.

Manser E, Huang H-A, Loo T-H, Chen X-Q, Dong J-M, Leung T, Lim L (1997) Expression of constitutively active $\alpha$-PAK reveals effects of the kinase on actin and focal complexes. Mol Cell Biol 17:1129-1143.

Minturn JE, Geschwind DH, Fryer HJL, Hockfield S (1995a) Early postmitotic neurones transiently express TOAD-64, a neural specific protein. J Comp Neurol 355:369-379.

Minturn JE, Fryer HJL, Geschwind DH, Hockfield S (1995b) TOAD64, a gene expressed early in neuronal differentiation in the rat, is related to unc-33, a C-Elegans gene involved in axon outgrowth. J Neurosci 15:6757-6766.

Newsome TP, Schmidt S, Dietzl G, Keleman K, Asling B, Debant A, Dickson BJ (2000) Trio combines with Dock to regulate Pak activity during photoreceptor pathfinding in Drosophila. Cell 101:283-294.

Nikolic M, Dudek H, Kwon YT, Ramos YFM, Tsai L-H (1996) The CDK5/p35 kinase is essential for neurite outgrowth during neuronal differentiation. Genes Dev 10: 816-825.

Nikolic M, Chou MM, Lu W, Mayer BJ, Tsai L-H (1998) The p35/ CDK5 kinase is a neuron specific Rac effector that inhibits PAK activity. Nature 395:194-198.

Obermeier A, Ahmed S, Manser E, Yen SC, Hall C, Lim L (1998) PAK promotes morphological changes by acting upstream of Rac. EMBO J 17:4328-4339.

Ohshima T, Ward JM, Huh CG, Longenecker,G, Veeranna, Pant HC, Brady RO, Martin LJ, Kulkarni AB (1996) Targeted disruption of the cyclin dependent kinase 5 gene results in abnormal corticogenesis, neuronal pathology and perinatal cell death. Proc Natl Acad Sci USA 93:11173-11178.

O'Leary DDM, Wilkinson DG (1999) Eph receptors and ephrins in neural development. Curr Opin Neurobiol 9:65-73.

Patrick G, Zuckerberg L, Nikolic M, De La Monte S, Dikkes P, Tsai LH (1999) Conversion of p35 to p25 deregulates Cdk5 activity and promotes neurodegeneration. Nature 402:612-622.

Ren X-R, Du O-S, Huang Y-Z, Ao S-Z, Mei L, Xiong WC (2001) Regulation of Cdc42GTPase by Proline-rich Tyrosine Kinase 2 interacting with PSGAP, a novel plekstrin homology and Src homology 3 domain containing RhoGAP protein. J Cell Biol 152:971-983.

Sarner S, Kozma R, Ahmed S, Lim L (2000) Phosphatidylinositol 3-kinase, Cdc42, and Rac1 act downstream of Ras in integrindependent neurite outgrowth in N1E-115 neuroblastoma cells. Mol Cell Biol 20:158-172.

Songyang Z, Gish G, Mbamalus G, Pawson T, Cantley LC (1995) A single point mutation switches the specificity of group III Src homology $(\mathrm{SH}) 2$ domains to that of group I SH2 domains. J Biol Chem 270:26029-26032.

Taylor JM, Macklem MM, Parsons JT (1999) Cytoskeletal changes induced by GRAF, the GTPase regulator associated with focal adhesion kinase, are mediated by Rho. J Cell Sci 112:231-242.

Teo M (1994) Purification and functional characterization of brain and recombinant chimaerin, a p21RAC GTPase activating protein, $\mathrm{PhD}$ thesis, University of London.

Thornton KH, Mueller WT, McConnell P, Zhu G, Saltiel AR, Thanabal V (1996) Nuclear magnetic resonance solution structure of the growth factor receptor bound protein 2 Src homology 2 domain. Biochemistry 35:11852-11864.

Threadgill R, Bobb K, Ghosh A (1997) Regulation of dendritic growth and remodeling by Rho, Rac and Cdc42. Neuron 19:625-634.

Tsai LH, Takahashi T, Caviness Jr VS, Harlow E (1993) Activity and expression of cyclin dependent protein kinase 5 in the embryonic nervous system. Development 119:1029-1040.

van Leeuwen FN, Kain HET, van der Kammen RA, Michaels F, Kranenburg OW, Collard JG (1997) The guanine nucleotide exchange factor Tiam1 affects neuronal morphology; opposing roles for the small GTPases Rac and Rho. J Cell Biol 139:797-807.

Vastrik I, Eickholt BJ, Walsh FS, Ridley A, Doherty P (1999) Sema3Ainduced growth-cone collapse is mediated by Rac1 amino acids 17-32. Curr Biol 9:991-998.

Wahl S, Barth H, Ciossek T, Aktories K, Mueller BK (2000) Ephrin-A5 induces collapse of growth cones by activating Rho and Rho-kinase. J Cell Biol 149:263-270.

Waksman G, Kominos D, Robertson SC, Pant N, Baltimore D, Birge RB, Cowburn D, Hanafusa H, Mayer BJ, Overduin M, Resh MD, Rios CB, Silverman L, Kuriyan J (1992) Crystal-structure of the phosphotyrosine recognition domain $\mathrm{SH} 2$ of $\mathrm{v}$-Src complexed with tyrosinephosphorylated peptides. Nature 358:646-653.

Waksman G, Shoelson SE, Pant N, Cowburn D, Kuriyan J (1993) Binding of a high-affinity phosphotyrosyl peptide to the Src SH2 domaincrystal-structures of the complexed and peptide-free forms. Cell 72:779-790.

Wang L-H, Strittmatter SM (1996) A family of rat CRMP genes is differentially expressed in the nervous system. J Neurosci 16:6197-6207.

Whittaker VP, Barker LA (1972) The subcellular fractionation of brain tissue with special reference to the preparation of synaptosomes and their component organelles. In: Methods of neurochemistry 2, (Fried R, ed), p 1. New York: Dekker.

Xiao JH, Davidson I, Matthes H, Garnier JM, Chambon P (1991) Cloning expression and transcriptional properties of the human enhancer factor TEF-1. Cell 65: 551-568.

Zheng M, Leung CL, Liem RKH (1998) Region-specific expression of cyclin-dependent kinase 5 (cdk5) and its activators, p35 and p39, in the developing and adult rat central nervous system. J Neurobiol 35:141-159. 